ESTELA KOBASHIGAWA

Lisina digestível e zinco quelato para frango de corte macho na fase dos 22 aos 42 dias de idade 


\title{
Lisina digestível e zinco quelato para frango de corte macho na fase dos 22 aos 42 dias de idade
}

Dissertação apresentada ao Programa de PósGraduação em Nutrição e Produção Animal da Faculdade de Medicina Veterinária e Zootecnia da Universidade de São Paulo para obtenção do título de mestre em Medicina Veterinária

\section{Departamento:}

Nutrição e Produção Animal

\author{
Área de Concentração: \\ Nutrição e Produção Animal
}

\section{Orientador:}

Prof. Dr. Messias Alves da Trindade Neto 
Autorizo a reprodução parcial ou total desta obra, para fins acadêmicos, desde que citada a fonte.

DADOS INTERNACIONAIS DE CATALOGAÇÃO-NA-PUBLICAÇÃO

(Biblioteca Virginie Buff D'Ápice da Faculdade de Medicina Veterinária e Zootecnia da Universidade de São Paulo)

T.1819 Kobashigawa, Estela

FMVZ Lisina digestível e zinco quelato para frango de corte macho na fase dos 22 aos 42 dias de idade / Kobashigawa, Estela. - Pirassununga: E. Kobashigawa, 2006.

$61 \mathrm{f}$. : il.

Dissertação (mestrado) - Universidade de São Paulo. Faculdade de Medicina Veterinária e Zootecnia. Departamento de Nutrição e Produção Animal, 2006.

Programa de Pós-graduação: Nutrição e Produção Animal.

Área de concentração: Nutrição e Produção Animal.

Orientador: Prof. Dr. Messias Alves da Trindade Neto.

1. Balanço de nitrogênio. 2. Composição corporal. 3. Deposição lipídeo e proteína. 4. Desempenho. Rendimento. I. Título. 


\section{UNIVERSIDADE DE SÃO PAULO \\ Faculdade de Medicina Veterinária e Zootecnia \\ Comissão de Bioética}

\section{PARECER}

Interessado: Estela Kobashigawa

Assunto: Protocolo de experimentação adotado em experimento animal.

A Comissão de Bioética da Faculdade de Medicina Veterinária e Zootecnia da Universidade de São Paulo, após analisar o projeto sob o número 885/2006, intitulado: "Lisina digestível e zinco orgânico para frangos de corte machos na fase final de crescimento (22-42 dias)", utilizando 1080 (um mil e oitenta) frangos de corte, sob responsabilidade do Prof. Dr. Messias Alves da Trindade Neto constatou que o mesmo foi realizado de acordo com os princípios de bioética, adotados por esta Comissão.

São Paulo, 18 de maio de 2006

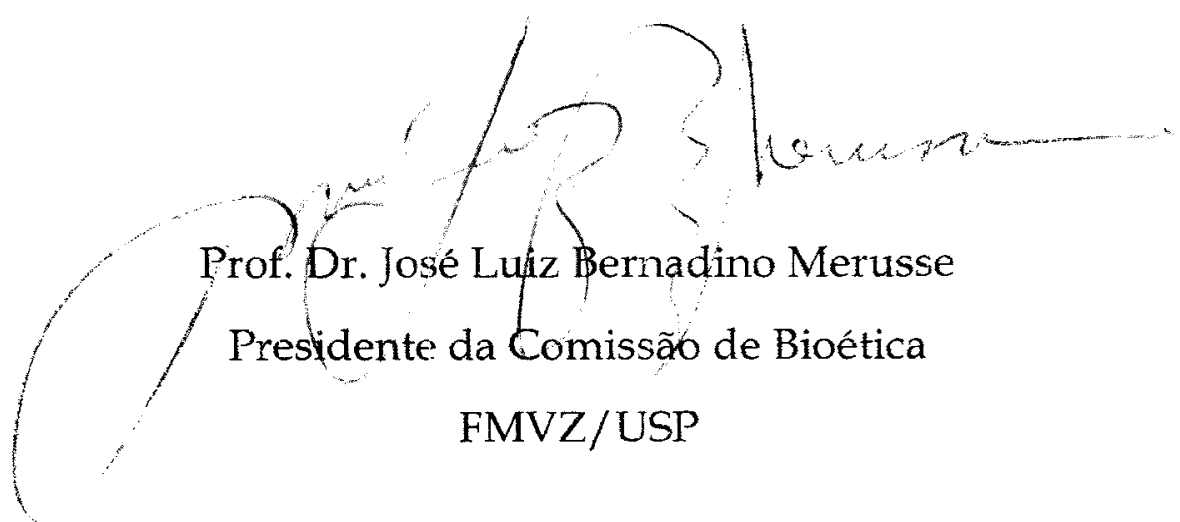




\section{FOLHA DE AVALIAÇÃO}

Nome: KOBASHIGAWA, Estela

Título: Lisina digestível e zinco quelato para frango de corte macho na fase dos 22 aos 42 dias de idade

Dissertação apresentada ao Programa de PósGraduação em Nutrição e Produção Animal da Faculdade de Medicina Veterinária e Zootecnia da Universidade de São Paulo para obtenção do título de Mestre em Medicina Veterinária

Data:

\section{Banca Examinadora}

Prof. Dr. Instituição:

Assinatura: Julgamento:

Prof. Dr. Instituição:

Assinatura: Julgamento:

Prof. Dr. Instituição:

Assinatura: Julgamento: 
A meus pais, Sadako e Paulo Sussumo Kobashigawa, e a meu irmão, Sérgio Kobashigawa.

Eu amo vocês! Mesmo que não possamos estar sempre juntos. 


\section{AGRADECIMENTOS}

Gostaria de agradecer à Universidade de São Paulo, Faculdade de Medicina Veterinárina e Zootecnia, Departamento de Nutrição e Produção Animal por oferecer o Curso de Pós-Graduação em Nutrição Animal.

Ao diretor do Instituto de Zootecnia, através do Doutor Guilherme Aleoni, responsável pelo Laboratório de Carnes, as funcionárias de apoio Dona Olinda e Dona Antônia pela consecução de parte deste trabalho.

Às empresas Ajinomoto Biolatina Indústria e Comércio Ltda. e Tortuga Companhia Zootécnica Agrária pelo fornecimento dos aminoácidos e suplementos utilizados nas dietas experimentais.

Ao Prof. Dr. Felix (in memorian), um dos responsáveis por meu ingresso no Programa de Pós-Graduação de Nutrição Animal. Não sei como lhe agradecer por ter acreditado em $\operatorname{mim}$ !

Ao Prof. Dr. Messias Alves da Trindade Neto, por me aceitar como orientada após o falecimento do professor Felix. Por me ajudar a encontrar luz quando estive perdida no meio dos meus resultados. Meu muitíssimo obrigada!

Aos professores Ricardo, Augusto e Maria de Fátima pela inestimável amizade, que com certeza levarei por toda minha vida, pelas pessoas maravilhosas que são e por fazerem deste, um mundo melhor!

Ao professor Paulo Henrique Mazza Rodrigues pelo oferecimento da disciplina SAS (VNP 5723-3) que sem ela não poderia ter analisado meus dados.

Pela dedicação dada ao Programa, agradeço aos professores Marcos Veiga dos Santos, Paulo Henrique Mazza Rodrigues, Luis Felipe, Romualdo Shigueo Fukushima, Aníbal Sant’Anna Moretti, Alexandre Gobesso e Francisco Rennó que tanto contribuem pelo crescimento do Departamento de Nutrição Animal, departamento este que amo de paixão! Minha sincera admiração.

Ao professor Fagundes, espero que se recupere logo...

Ao professor Lúcio Francelino Araújo, grande profissional, que tive oportunidade de conhecer durante o cotidiano no aviário!

Aos amigos Francine, Paulinha, Luiz Felipe, Raquel Helena (Bete), Fernanda Altieri (Xeila), Rafael, Claudinha Fernandes, Vivianne (Fonfon) que me serviram de alicerce nos momentos difíceis. Anjos maravilhosos que Deus pôs em meu caminho!

Um agradecimento especial a Daniel Gonçalves Bruno ;) 
Aos funcionários China, Edinho, Cristiane, Alessandra, Zequinha, Ari, Simi e Gilson, da Fábrica de Ração (Edil, Cláudio, Israel, Itaci e Zezinho) e do Abatedouro Escola (Élcio, Beloni, Maurício Pagotto, Maurício Charlac, Mário, Dorival e Benedito) que tornaram possível a realização desta dissertação. Meu agradecimento especial!

Aos funcionários Lucinéia, Zequinha, Gilmar, Everson, Fabinho, Maria, Claudimara, Patrícia, Cecília, Reinaldo (Cebolinha), Bigode (Humberto), Limarque, Marcão, Lurdes, Ogna, guardas (Luciano, Almeida, Sebastião, Lesbon) e seu Pedro pelo bom convívio diário.

Aos amigos Ana Louise, Letícia, Marcos Barbosa, Rodrigo Ribeiro, Waleska, André (Pesquêro), Estela Alves, Gilson (Doug), Vinícius, Ana Paula, Carolina Fernanda, Carol Bacha, Willian, Bruno Botaro, Lilian, Agostinho, Milena, Flávio (Tenébrio), Paulo César (Chileno), Simone amigos e companheiros especiais.

Aos colegas que tive oportunidade de conhecer através deste programa: Laura, Poliana, Cristiane, Aline Rosseto, Ubatuba, Abrãao, Edson, Ricardo Lobo, Marcos Pinesi, Sabrina e Aline.

Ao aluno de graduação Maurício Voss Rodrigues que auxiliou na realização da parte experimental e alunos da 69 $9^{\mathrm{a}}$ 70 e $71^{\mathrm{a}}$ turmas do Curso de Medicina Veterinária e Zootecnia da Universidade de São Paulo.

Aos novos colegas do Programa, Camila, Pascoal, Walter, Artur, Renata, Alessandra, Aryana, Diego, Samuel, Andréia.

À Júlia Thomaz pela correção gramatical, tradução para o inglês e pela amizade que criamos durante as aulas de Francês.

A Júlio César Papesso, que mesmo distante, sei que torce por mim.

A Deus que sempre me ajudou em todos os momentos e que sempre coloca pessoas maravilhosas e de bom coração em minha vida. 


\section{RESUMO}

KOBASHIGAWA, E. Lisina digestível e zinco quelato para frango de corte macho na fase dos 22 aos 42 dias de idade. [Digestible lysine and zinc chelate for male broilers from 22 to 42 days of age]. 2006. 61 f. Dissertação (Mestrado em Medicina Veterinária) Faculdade de Medicina Veterinária e Zootecnia, Universidade de São Paulo, Pirassununga, 2006.

Foram realizados dois ensaios experimentais a fim de avaliar diferentes níveis de lisina digestível e zinco quelato para frango de corte macho, da linhagem Ross na fase dos 22 aos 42 dias de idade. $\mathrm{O}$ delineamento experimental foi inteiramente casualizado em arranjo fatorial 5 x 2, cinco níveis de lisina e dois níveis de zinco 43 e 243ppm. As dietas foram formuladas para conter $3.150 \mathrm{kcal}$ de EM/kg e 19\% de PB. No ensaio I, os níveis de lisina digestível foram 0,841, 0,874, 0,995, 1,019 e 1,028\%, aplicados a três unidades experimentais. A unidade experimental correspondeu a 1 boxe com 30 frangos com peso médio inicial de 957,38g. Avaliaram-se características de desempenho, rendimento de cortes e composição corporal. No ensaio II, os níveis de lisina digestível foram 0,779, 0,825, 0,961, 1,066 e 1,222\%, aplicados a seis repetições .A unidade experimental correspondeu a uma gaiola com três animais com peso médio inicial de 866,22g. Determinou-se, nesse estudo, o balanço de nitrogênio e a digestibilidade das dietas. Constatou-se interação do nível de lisina e zinco nas variáveis: peso final, ganho de peso, conversão alimentar, matéria seca ingerida, nitrogênio ingerido, energia bruta ingerida, energia bruta excretada e balanço energético. Porcentagem de peito e porcentagem de coxa e sobrecoxa foram crescentes pelo aumento na concentração de lisina digestível na dieta, seguindo equação linear. O melhor nível de lisina, de acordo com o desempenho, foi de $1,06 \%$ de lisina total ou $0,93 \%$ de lisina digestível para dietas com 43ppm de zinco. Para dietas com 253ppm, a exigência de lisina digestível foi igual ou maior que $1,028 \%$.

Palavras-chave: Balanço de nitrogênio. Composição corporal. Deposição lipídeo e proteína. Desempenho. Rendimento. 


\begin{abstract}
KOBASHIGAWA, E. Digestible lysine and zinc chelate for male broilers from 22 to 42 days of age. [Lisina digestível e zinco quelato para frango de corte macho na fase dos 22 aos 42 dias de idade]. 2006. 61 f. Dissertação (Mestrado em Medicina Veterinária) - Faculdade de Medicina Veterinária e Zootecnia, Universidade de São Paulo, Pirassununga, 2006.
\end{abstract}

In order to evaluate the different levels of digestible lysine and zinc chelate effect on Ross male broiler chicken from 22 to 42 days of age, two trials were carried out. The experimental design was completely randomized with a $5 \times 2$ arrangement, with treatments consisting of five levels of lysine and two levels of zinc chelate (43 and 243ppm). All diets contained 3,150 kcal of $\mathrm{ME} / \mathrm{kg}$ and $19 \%$ of crude protein. In trial I, a 30 poultry pen was considered one experimental unit and three pens received the following lysine levels: 0.841, 0.874, 0.995, 1.019 and $1.028 \%$. Average weight at pen was 957.38g. For this trial, parameters evaluated were: performance traits, cut yield and body composition. In trial II, each three birds cage, weighting 866.22g in average, was considered one experimental unit. Birds were fed in repetition another five lysine levels: 0.779, 0.825, 0.961, 1.066 and 1.222\%. In this latter trial, data on nitrogen-balance and diets digestibility were determined. Interaction between lysine and zinc chelate was observed for weight at day 42, weight gain, feed:ration gain, dry matter intake, nitrogen intake, crude energy intake, crude energy excreted and energy balance. There was an increasing in breast, thigh and drumstick percentage concomitant with the increase of lysine levels on diet, following a linear equation. The most effective lysine level, accordingly to performance traits, was $1.06 \%$ of total lysine, or $0.93 \%$ of digestive lysine, when the zinc chelate level was 43ppm. A 253ppm diets required lysine levels of $1.028 \%$ or greater.

Key worlds: $\quad$ Body composition. Cut yield. Lipid and protein deposition. Nittrogen balance. Performance. 


\section{LISTA DE FIGURAS}

Figura 1 - Estrutura molecular do fosfocarboquelato de zinco.............................. 23

Figura 2 - Ganho em peso estimado, em função do nível de lisina digestível e zinco quelato na dieta....................................................................... 34

Figura 3 - Consumo de matéria seca em função dos níveis de zinco quelato e lisina digestível na dieta...................................................................... 48 


\section{LISTA DE TABELAS}

Tabela 1 - Composição das dietas experimentais na fase dos 22 aos 42 dias de idade

Tabela 2 - Valores nutricionais analisados e estimados das dietas fornecidas durante o experimento I, para avaliação de desempenho, rendimento e composição corporal.

Tabela 3 - Valores nutricionais analisados e estimados das dietas fornecidas durante o experimento II, para avaliação de balanço de nitrogênio....... 28

Tabela 4 - $\quad$ Desempenho de frangos de corte em função do nível nutricional.......... 36

Tabela 5 - $\quad$ Rendimento de cortes em função do nível nutricional........................... 38

Tabela 6 - Composição química do corpo vazio na matéria natural em função do nível nutricional............................................................................ 40

Tabela 7 - Composição química da carcaça em função do nível nutricional........... 42

Tabela 8 - Composição química de sangue vísceras em função do nível

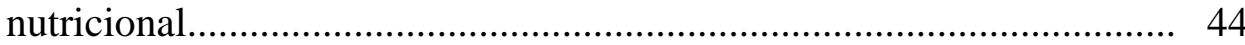

Tabela 9 - $\quad$ Deposição de nutrientes na carcaça e no corpo vazio em função do nível nutricional............................................................................... 46

Tabela 10 - Digestibilidade das dietas em função do nível nutricional.................... 49

Tabela 11 - Valores de energia das dietas em função do nível nutricional................ 52 
1 INTRODUÇÃO..................................................................................... 13

2 OBJETIVOS............................................................................................ 16

$3 \quad$ REVISÃO DE LITERATURA.................................................................. 17

NIIVEIS NUTRICIONAIS DE LISINA........................................... 19

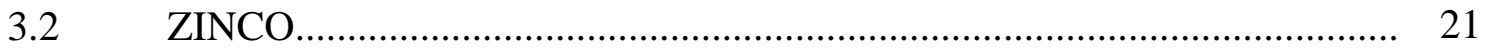

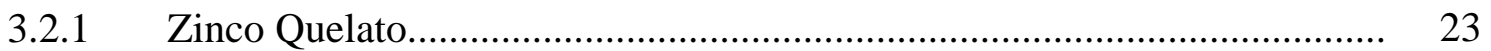

4 MATERIAIS E MÉTODOS...................................................................... 24

4.1 LOCAL E INSTALAÇÕES............................................................... 24

4.2 DELINEAMENTO E TRATAMENTOS EXPERIMENTAIS.................... 25 PROCEDIMENTOS PARA DETERMINAÇÃO DA COMPOSIÇÃO

4.3 QUÍMICA CORPORAL ................................................................ 29

$4.4 \quad$ E ANÁLISES .................................................................................. 30

4.5 BALANÇO DE NITROGÊNIO............................................................... 31

4.6 COEFICIENTE DE DIGESTIBILIDADE ............................................ 31

4.7 VARIÁVEIS AVALIADAS E ANÁLISE ESTATÍSTICA........................ 32

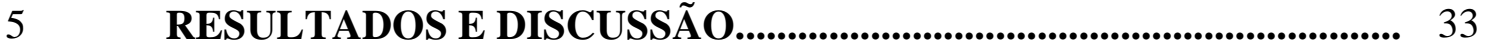

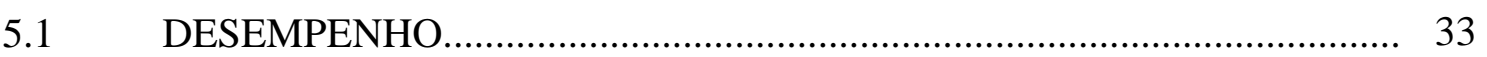

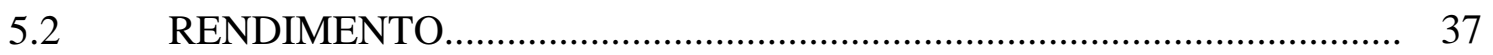

COMPOSIÇÃO QUÍMICA CORPORAL .................................................. 40

5.4 BALANÇO DE NITROGÊNIO............................................................. 48

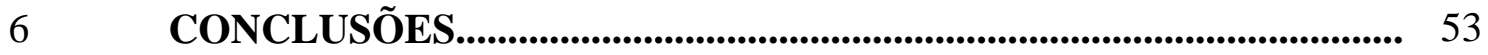

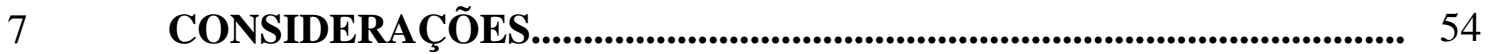

REFERÊNCIAS..................................................................................... 55 


\section{INTRODUÇÃO}

No Brasil, a avicultura surgiu no estado de Minas Gerais por volta de 1860. Naquela época, as aves eram criadas soltas e demoravam cerca de seis meses para atingirem o peso de abate (2,5kg). Com a necessidade de abastecer os mercados, o processo de modernização e de produção em escala no Brasil desenvolveu-se a partir da década de 30. Na década de 50, com avanços na genética, aprimoramento de vacinas, nutrição e produção de equipamentos específicos para a criação, a avicultura brasileira ganhou impulso. Hoje, o país é o maior exportador e o segundo maior produtor de carne de frango do mundo.

Ao longo das últimas décadas, houve intensa seleção genética em aves destinadas à produção de carne e ovos, cujas características selecionadas, estabeleceram a distinção no desempenho entre as linhagens existentes no mercado da avicultura. Além das perspectivas no aumento da produtividade, as diretrizes e ações do melhoramento genético e da nutrição são voltadas para as exigências do mercado consumidor, elo final da cadeia produtiva.

Dessa forma, dentro de um contexto em que se buscam avanços no desempenho para a produção de proteína animal, os estudos dos nutrientes e/ou formulações de dietas deverão ser revistos, periodicamente, a fim de que se evitem níveis acima ou abaixo dos sugeridos.

Em ambos os casos, além das implicações negativas no plano financeiro, podem ocorrer também prejuízos ao meio ambiente, visto que nutrientes dietéticos,quando não utilizados na deposição protéica, são perdidos nas fezes e lançados ao solo, a exemplo do nitrogênio, tornando-se um dos principais poluentes de mananciais e lençóis freáticos.

Estima-se que o ganho em produtividade de origem genética, na avicultura de corte, fique em torno de 85 a 90\%. Torna-se necessário, portanto, oferecer condições ideais para que os animais possam expressar todo seu potencial genético. A nutrição, neste caso, é parte fundamental dessas condições.

Cerca de 70\% do custo de produção é devido à nutrição da ave. Nunes et al. (2000) revisando trabalhos realizados no Brasil no período de 1994 a 1999, destacaram a importância da nutrição na avicultura. Dos 496 trabalhos científicos analisados, 64,52\% foram com frangos de corte, dos quais 22,19\% estavam relacionados à proteína e aminoácidos. Nutrientes esses, essenciais no desenvolvimento (acúmulo de massa muscular) corporal das aves.Durante muitos anos a dieta de aves foi baseada no conceito de proteína bruta, normalmente resultando em dietas com níveis de alguns aminoácidos acima das necessidades do animal. O excesso de proteína pode deprimir a utilização dos aminoácidos mais limitantes na dieta à base de milho 
e farelo de soja. Os aminoácidos em excesso são desaminados e excretados na forma de ácido úrico, processo esse que impõe gasto energético para o animal (LECLERCQ, 1996). O organismo animal ao incorporar 1 aminoácido na cadeia protéica gasta 4 mol de ATP, enquanto que em sua excreção de gasta 6 a 18 mol de ATP (MCLEOD; 1997).

O aumento da disponibilidade dos aminoácidos industriais possibilitou a diminuição dos níveis dietéticos da proteína e a melhor adequação das concentrações dos aminoácidos às exigências da ave.

Alguns autores relatam que o consumo excessivo de aminoácidos prejudica o desempenho das aves, eleva o custo de formulação das dietas, incrementa o calor metabólico e contribui com a excreção de nitrogênio (BERCOVICI; SUIDA, 1998). Os autores também destacam, além dos prejuízos citados, o aumento da incidência de problemas sanitários associados à qualidade da cama, sobre a qual os animais normalmente se encontram no interior dos galpões de criação

A redução da proteína da dieta, no conceito de proteína ideal, foi definida primeiramente por Mitchell (1964). Segundo o autor, o conceito implica na necessidade de cada aminoácido essencial ser expresso na relação porcentual ao aminoácido referência, possibilitando a diminuição dos níveis dietéticos da proteína e a melhor adequação das concentrações dos aminoácidos às exigências da ave.

O aminoácido referência no conceito da proteína ideal é a lisina. Nessa escolha levouse em consideração a ordem de limitação dos aminoácidos essenciais em suínos e aves, cujas dietas se baseiam em milho e farelo de soja.

A lisina é o primeiro aminoácido limitante para suínos e o segundo para aves. Além de ser priorizado na deposição protéica, esse aminoácido é de fácil determinação analítica (PACK, 1995; ZAVIEZO, 2000).

No estabelecimento das exigências nutricionais de aves, deve-se levar em conta alguns fatores determinantes na eficiência de utilização dos nutrientes dietéticos oferecidos em um plano nutricional. Dentre eles: raça, linhagem, sexo, idade, taxa de consumo, nível energético da dieta, disponibilidade dos nutrientes dietéticos, temperatura ambiente, umidade do ar e estresse imunológico (D’MELLO, 2003; ROSTAGNO et al., 2000).

Quanto à disponibilidade de nutrientes, algumas bactérias do trato gastrointestinal podem sintetizar vitaminas e aminoácidos essenciais para o hospedeiro. Existem as aquelas que competem com os animais pelos nutrientes e nesse caso, alteração da microflora também pode propiciar maior aporte de nutrientes ao hospedeiro (BELLAVER, 2000). Muramatsu et al. (1987) observaram que a síntese protéica do intestino e fígado de pintinhos criados em 
condições convencionais, era $36 \%$ maior comparados àqueles livres de patógenos. Concluíram, assim, que nos tecidos mais expostos à ação microbiana, a síntese protéica foi maior.

A presença de microflora entérica afeta a estrutura, função e trocas ("turn-over”) protéicas nos tecidos intestinais, portanto, o balanço energético e protéico podem ser alterados por agentes microbianos e pela manipulação da microflora entérica (RUTZ; LIMA, 2001).

Com relação à manipulação da microflora entérica, Rutz e Lima (2001) relataram que em altas concentrações na dieta, o zinco apresenta propriedades antibacterianas. O zinco também tem ação fundamental na imunidade humoral (produção de imunoglobulinas pelos linfócitos B), na resposta celular e na maturação de linfócitos T no timo (FRAKER et al., 2000). Em camundongos, a deficiência de zinco, afeta a resposta imune da mucosa intestinal e pode prolongar a sobrevivência de parasitas no intestino (SCOTT; KOSKI, 2000).

A presente proposta deteve-se na avaliação de níveis nutricionais em frangos de corte, criados com separação de sexo a partir do primeiro dia de vida, observando-se o excesso ou déficit de nutrientes na limitação da expressão do potencial genético. A pesquisa destinou-se ao estudo da linhagem Ross, criada nas condições climáticas da região de Pirassununga, SP. 


\section{OBJETIVOS}

- Avaliar os efeitos do nível de lisina e do nível de zinco quelato para frangos de corte machos da linhagem Ross, dos 22 aos 42 dias de idade, aplicáveis à região de Pirassununga - SP.

- Sugerir níveis com base no ganho em peso, consumo de ração, conversão alimentar, composição química corporal, taxas de deposição de nutrientes corporais, balanço de nitrogênio, rendimento de carcaça e de cortes. 


\section{REVISÃO DE LITERATURA}

Devido ao extraordinário desenvolvimento do frango de corte, do nascimento ao abate, cria-se um grande desafio em estabelecer, com acurácia, os níveis nutricionais exigidos nas diversas fases do seu desenvolvimento. A máxima capacidade para ganho em peso ocorre na primeira semana de vida, quando a ave multiplica seu peso ao nascer cerca de $340 \%$. Da segunda semana para o final da primeira, essa diferença reduz para $270 \%$ e nas seguintes vai se reduzindo até $110 \%$ na sétima em relação à sexta (FERNANDES, 2001). Como foram abordados anteriormente, diversos fatores determinam a resposta de crescimento do frango, dentre os quais se destacam o material genético e o ajuste dos nutrientes, de acordo com as exigências para as diferentes fases da criação.

Com o avanço genético das linhagens de frangos de corte e a manifestação de características superiores de desempenho e de carcaça, faz-se necessária contínua atualização das exigências nutricionais (BELLAVER et al., 2002). No atual estágio da busca de conhecimentos acerca das reais demandas nutricionais dos animais monogástricos selecionados para alta produção de carne, há que se considerar as especificidades do material genético em estudo (D’MELLO, 2003).

Uma vez controlados alguns fatores que influenciam a eficiência de utilização dos nutrientes dietéticos para o desempenho, é fundamental determinar níveis mais precisos dos nutrientes que permitam a expressão máxima do potencial genético. Expressão esta, caracterizada pelo ganho de peso, eficiência de utilização de nutrientes, deposição de tecidos, composição química corporal e qualidade de carcaça.

No que diz respeito à alimentação, a dieta ideal deve conter quantidades e relações desejáveis entre os nutrientes de modo a permitir que o animal supra suas necessidades de mantença e de produção. Os componentes da nutrição, com maior importância para os animais monogástricos são: a proteína, os carboidratos, os lipídeos, as vitaminas e os minerais. Dentre eles, a proteína é o componente nutricional de maior custo na dieta de frangos, representando cerca de 40 a 50\% do custo total (SAKOMURA, 1998). Os níveis dietéticos de proteína, entretanto, devem ser vistos apenas como indicativos, uma vez que o fornecimento dos aminoácidos essenciais tem maior importância (ROSTAGNO et al., 2000).

As necessidades de proteína decompõem-se em exigências por aminoácidos que são as unidades estruturais primárias formadoras do tecido muscular e outras proteínas presentes no corpo animal: pêlos, penas, pele, enzimas digestivas e metabólicas e sangue (FULLER; 
WANG, 1990). No entanto, na determinação das exigências dos aminoácidos, as variações na síntese protéica ocorridas em função do peso corporal teriam relação com a fração da energia dietética disponível para o metabolismo. Essa é uma importante consideração no sucesso dos programas de alimentação multifásica de aves e nas metas para diminuírem a excreção de nitrogênio.

Os aminoácidos são nutrientes essenciais para aves e suínos e precisam ser supridos na dieta em concentrações balanceadas para maximizar o desempenho durante o crescimento. Provenientes da correta combinação dietética, os aminoácidos, são depositados como proteína, representada pela síntese e acúmulo de tecido muscular na carcaça (FULLER, 1990; WHITTEMORE; ELSLEY, 1976). Observa-se, porém, que as recomendações para atender exigências de aminoácidos em diferentes países decorrem das condições de alojamento e do ambiente, genótipo animal, programas alimentares, ingredientes empregados nas rações, principalmente os protéicos, e critérios para avaliação das respostas nos parâmetros de interesse (JONGBLOED; LENIS, 1992). Com base nessas variáveis, que afetam o desempenho das aves, experimentos têm sido conduzidos com o intuito de quantificar os efeitos do consumo de lisina no desempenho e composição corporal (CELLA et al., 2001; LANA et al. 2005).

Aminoácidos industriais tais como lisina, metionina, treonina e triptofano têm significativa participação na aplicabilidade do conceito de proteína ideal para aves. Também têm se mostrado viável em pesquisas que visam a redução do nível de proteína bruta nas rações, atendendo as exigências nutricionais de aminoácidos através de suplementação. Assim, é possível evitar o excesso de aminoácidos, aumentar a eficiência de utilização da proteína e reduzir a poluição ambiental em função da menor excreção de nitrogênio (DESCHEPPER; DE GROOTE, 1995; HURWITZ et al., 1998).

O potencial de deposição protéica da ave é pré-determinado pela constituição genética, enquanto a deposição diária de gordura é proporcional a quantidade de energia disponível para a síntese (LEESON; CASTON; SUMMERS, 1996), após serem atendidas as demandas de manutenção das atividades corporais e do crescimento muscular. A determinação do pico ou a máxima deposição protéica caracteriza a eficiência máxima da utilização dos aminoácidos para a síntese e acúmulo de massa muscular na carcaça.

A deposição lipídica tende a aumentar quando o animal em crescimento atinge a máxima deposição protéica. A partir daí, a deposição protéica se estabiliza e a deposição lipídica poderá ocorrer em demasia se a ingestão de energia estiver acima das demandas do metabolismo basal e termogênese. Nesse estágio, deve-se atentar à menor taxa de crescimento 
da ave, quando ocorre o acúmulo lipídico. O fornecimento adequado de energia na ração, portanto, é fundamental para que se evite o previsto e excessivo acúmulo de gordura na carcaça.

Constantes avanços no manejo, ambiência, sanidade e melhoramento genético de aves determinam a necessidade permanente de reavaliação e atualização das exigências nutricionais da espécie.

É preciso estar atento a todas as possíveis situações e fatores que determinem o sucesso na produção de carne e produtos afins de alta qualidade. Para que se obtenha um elevado padrão produtivo, novos parâmetros que determinarão o estágio de produtividade ou eficácia devem estar inseridos nesse contexto. São eles: o desempenho ponderal, a decomposição do ganho diário e a deposição de nutrientes corporais. Essas medidas refletirão a eficiência de utilização dos nutrientes dietéticos, aplicados a determinadas fases do desenvolvimento, conforme a especificidade de cada uma, inerente àquele animal, regida pela combinação de fatores, cuja somatória estabelece o conceito de bem estar animal e baixo impacto ambiental.

Nesse sentido, a presente proposta é focada para a determinação mais ajustada de níveis nutricionais em diferentes regiões de desenvolvimento do frango de corte criado com separação de sexo a partir do primeiro dia de vida. Com tais ajustes, objetiva-se evitar os excessos ou déficits de nutrientes que limitem a expressão do potencial genético ou afetem, negativamente, o meio ambiente.

\subsection{NÍVEIS NUTRICIONAIS DE LISINA}

A lisina é o aminoácido mais exigido em quantidade para a deposição protéica. Assim, consideraram-na como padrão. Ou seja, os demais aminoácidos essenciais são dados como uma porcentagem de seu conteúdo (FULLER; WANG, 1990; VAN LUNEN, 1995; WANG; FULLER, 1989 ).

Esse padrão de relação dos demais aminoácidos essenciais com a lisina possibilita a formulação de dietas ajustadas e precisas. Além der ser um dos aminoácidos limitantes para suínos e frangos de corte, a lisina é considerada “chave”, devido a características no metabolismo, o que a torna ideal para se estabelecer o perfil completo de aminoácidos (BELLAVER; VIOLA, 1997). 
Segundo Friesen et al. (1996) na fase de crescimento, a lisina destina-se, preferencialmente, à deposição muscular e algumas partes do corpo respondem melhor ao aumento da ingestão do aminoácido. Esse aumento da deposição protéica refletiria o número de células e a quantidade de proteína acumulada em cada célula. Portanto, animais com alta taxa de deposição protéica necessitam de maior concentração de lisina na dieta, devido à maior síntese diária de proteína muscular (FRIESEN et al., 1996; LAWRENCE; FOWLER, 1997).

O aumento da disponibilidade dos aminoácidos industriais vem possibilitando a formulação de dietas com os níveis de lisina próximos das necessidades das aves, de modo que o conteúdo da proteína bruta seja reduzido. Costa et al. (2001) estudando diferentes níveis de lisina para frangos de corte, da linhagem Ross, com 22 a 40 dias de idade, determinaram 1,164\% como o melhor nível.

Acar et al. (1991) ofereceram dieta com níveis de lisina que variavam de 0,75 a 1,15\% para frangos entre 6 e 8 semanas de idade de duas linhagens. Não observaram diferentes respostas para ganho em peso e conversão alimentar, mas constataram que a linhagem de crescimento lento depositou menos gordura abdominal e teve maior rendimento de peito.

Revisando o assunto sobre exigências de lisina, Susenbeth (1995) concluiu que as recomendações dependem de conhecimento sobre a eficiência de utilização deste aminoácido e seus efeitos na deposição protéica e lipídica. Sugeriu ainda que novas pesquisas deveriam focalizar este ponto, devido ao contínuo progresso da seleção genética. Rostagno et al. (1996) enfatizaram a necessidade de atualização permanente dos níveis nutricionais. Cabem ser destacados dados obtidos por Barboza (1998) quando determinou níveis de lisina acima daqueles recomendados pelo NRC-94 e UFV-90, utilizando as linhagens de corte Hubbard e Ross nas diversas fases de produção. No estudo em questão, os níveis determinados de lisina foram: 1,10\% dos 15 aos 40 dias de idade e 1,03\% dos 22 aos 40 dias de idade. Há, contudo, respostas contraditórias em estudos semelhantes, o que deve ser visto como preocupação adicional, no sentido de ajustar o aporte dos nutrientes dietéticos, de modo mais eficaz,. Isso deve ser feito com o isolamento dos possíveis fatores que determinam, conjuntamente, o potencial genético da linhagem de frango de corte.

Bellaver et al. (2002) enfatizou que o uso da proteína ideal tem grande vantagem na produção de linhagens melhoradas, pois permite o balanço entre os aminoácidos cristalinos, além de reduzir a excreção de nitrogênio. Outro importante aspecto a ser considerado em relação ao balanço ideal dos principais aminoácidos é a utilização desses conforme suas disponibilidades nos ingredientes. A relação ideal entre os principais aminoácidos tem sua 
aplicação mais justificada quando se enfatiza idade, sexo, situações de estresse por calor e condições sanitárias, nas quais os animais de rápido crescimento se encontram (BAKER et al., 1993).

\subsection{ZINCO}

Microelemento essencial, o zinco está envolvido na atividade de mais de 300 enzimas (MCCALL; HUANG; FIERKE, 2000) que encontram-se associadas aos processos biológicos dos animais. Apresenta várias funções catalíticas, estruturais e reguladoras, apesar das baixas concentrações na maioria dos órgãos. As metaloenzimas dependentes de zinco encontram-se distribuídas em todos os tecidos do organismo exercendo funções importantes, as quais se destacam a síntese e degradação de carboidratos, lipídeos e proteínas. Também é importante ao funcionamento adequado do sistema imunológico, da transcrição e da tradução de polinucleotídeos (SALGUEIRO, 2000). Dentre as enzimas dependentes de zinco associadas à síntese de RNA e DNA, a RNA polimerase, transcriptase reversa e fator de transição IIIA foram citada por MacDonald (2000).

O zinco exerce funções importantes no crescimento e desenvolvimento, atuando na diferenciação de condrócitos, osteoblastos e fibroblastos, no metabolismo de lipídios, e proteínas e na síntese hormonal (BRANDÃO NETO, 1995).

O IGF-1, hormônio polipeptídico que estimula a síntese de DNA e RNA, permanece em nível inalterado em alguns animais após receberem uma dieta deficiente em zinco, suplementada com proteína. Os mesmos animais, ao receberem uma dieta com baixo nível protéico com suplementação de zinco apresentam aumento na concentração do IGF-1 plasmático (COSSACK ${ }^{1}, 1986$ apud BRANDÃO NETO, 1995).

A absorção do zinco ocorre principalmente no intestino delgado (COUSINS, 1985), sendo transportado para o interior da membrana celular através de carreadores (UNDERWOOD; SUTTLE, 1999). Dentro da célula da mucosa, a transferência do zinco é realizada através da metalotioneína, proteína produzida no fígado, cuja síntese é influenciada pelos níveis dietéticos e plasmáticos de zinco (MCDOWELL, 1992).

\footnotetext{
${ }^{1}$ COSSACK, Z. T. Somatomedin-C and zinc status in rats as affected by Zn, protein and food intake. Br J Nutr, v. 56, p. 163-169. 1986.
} 
O zinco está distribuído por todo o organismo. No fígado é armazenado na forma da metalotioneína e no tecido ósseo funciona como reserva. Em excesso, é acumulado para ser liberado nas situações de deficiência (EMMERT; BAKER, 1995).

No alimento, admite-se que a presença de zinco não é indicativa de sua biodisponibilidade (MAFRA; COZZOLINO, 2004). Fatores antinutricionais presentes na dieta podem interagir com o zinco, complexando-o e afetando sua biodisponibilidade. A presença de fitatos e outros íons no alimento limita a utilização do zinco, devido a formação de quelatos indigeríveis, o que ocorre em condições normais de alimentação.

Frações expressivas do zinco presente no milho e farelo de soja encontram-se indisponíveis nas dietas de frangos de corte, em função da presença de fatores antinutricionais, como o ácido fítico. Dentre os fatores antinutricionais de maior destaque na alimentação dos monogástricos, o fitato tem recebido atenção devido sua ação formadora de compostos insolúveis com o zinco, cálcio e íons bivalentes.

Mohanna e Nys (1999) observaram que o nível de zinco na tíbia e no plasma teve aumento linear em resposta ao acréscimo de zinco na dieta. O pico do micromineral obtido foi aos 90 ppm. Verificaram também que o nível adequado para dietas de frangos até 21 dias de idade foi de 45 ppm. Valor próximo ao nível de 40ppm recomendados pelo NRC (1994). Burrell et al. (2004) no entanto, sugeriram níveis de 80 ppm para obtenção do maior ganho em peso com frangos de corte da linhagem Coob 500. Bartlett e Smith (2003) por outro lado, não encontraram diferenças no desempenho de frangos de corte, quando forneceram dietas com 34 ou 181ppm de zinco inorgânico.

\subsubsection{Zinco Quelato}

O zinco quelato consiste na união do íon metal, através de uma ligação coordenada covalente, com o grupo amino e, através de uma ligação coordenada covalente e ou iônica, com o grupo carboxila. Forma-se um anel heterocíclico com pelo menos um ligante nãometálico, geralmente um aminoácido (ALBITECH, 2006).

No carboquelato de zinco (carbo-amino-fosfo-quelato de zinco) utilizado no presente estudo, o zinco representa apenas 7\% da molécula, enquanto os outros 93\% são constituídos por aminoácido, fósforo e polissacarídeo (Figura 1). 


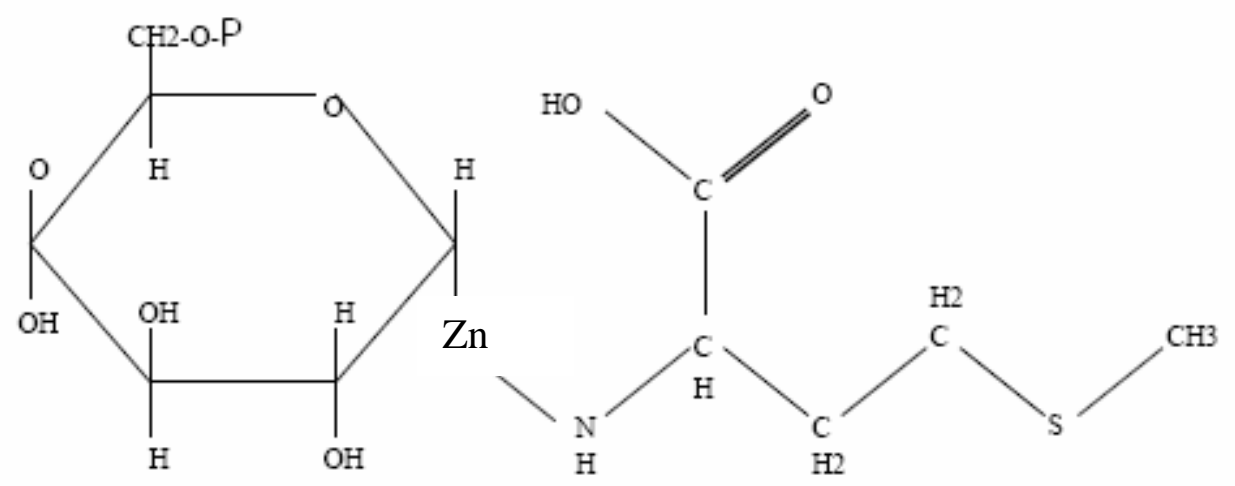

Figura 1 - Estrutura molecular do carboquelato de zinco

Spears et al. (1991) observou que a suplementação de zinco quelato na dieta de bovinos melhorou a imunidade, quando comparada à suplementação com zinco inorgânico.

Schlegel e Windisch (2006) adicionando fitato em dieta de ratos, observou a diminuição drástica na biodisponibilidade de zinco, quando comparado às dietas sem a adição de fitato. Quando utilizou zinco glicinato, no entanto, a queda na biodisponibilidade foi menor. De maneira geral, a forma orgânica do zinco apresenta-se mais biodisponível ao animal em relação à forma inorgânica (AOYAGI; BAKER,1993; WEDEKIND, 1994). Hess et al. (2001) estudando diferentes fontes de zinco na dieta de fêmeas de frango de corte, observou melhora na conversão alimentar quando utilizou zinco quelado com aminoácidos. Há estudos, entretanto, nos quais não foram observadas melhoras no desempenho de frangos de corte, quando zinco inorgânico foi substituído pelo zinco na forma orgânica (KIDD et al., 1994; MOHANNA; NYS, 1999; PIMENTEL et al., 1991).

Dejetos de frangos tornaram-se um problema ambiental, seja pelos níveis de nitrogênio e fósforo neles contidos, ou pela presença de metais pesados. Cerca de $94 \%$ do zinco da dieta é excretado (MOHANNA; NYS, 1997) Coic e Coppenet (1989) relataram que o uso de dejetos de frangos como adubo, baseado no nível de nitrogênio, possui 560\% mais zinco do que as plantas necessitam. Dessa forma, a utilização de zinco na forma orgânica reduz a excreção deste micromineral (BURRELL et al., 2004). Na forma orgânica, o zinco torna-se fonte alternativa na nutrição mineral, sem que haja prejuízo no desempenho dos animais. 


\section{MATERIAIS E MÉTODOS}

Os materiais e as metodologias utilizados neste trabalho estão descritos nos itens que seguem.

\subsection{LOCAL E INSTALAÇÕES}

Foram realizados dois ensaios experimentais no Setor de Avicultura da Faculdade de Medicina Veterinária e Zootecnia da Universidade de São Paulo, Campus de Pirassununga. O primeiro, realizado entre 11 de outubro e $1^{\circ}$ de novembro de 2005, teve a finalidade de avaliar o desempenho, rendimento de cortes, composição química e taxas de deposição corporal em frangos de corte. O segundo, realizado entre 2 de março e 8 de março de 2006, ocorreu para determinar o balanço de nitrogênio em frangos de mesma categoria e fase de desenvolvimento.

No estudo de desempenho, as aves foram instaladas em boxes, no piso de um galpão experimental construído em alvenaria, com aberturas laterais e cortinas para controle da ventilação e da temperatura interna. O galpão é dividido em 36 boxes de 4,25 m², equipados de comedouro tubular, bebedouro pendular e piso forrado com casca de arroz.

No estudo de metabolismo, as aves foram instaladas em gaiolas de arame galvanizado de 0,90 × $0,90 \times 0,50 \mathrm{~m}$ a $1 \mathrm{~m}$ de altura do piso. Gaiolas eram providas de comedouro tipo calha, bebedouro nipple e coletor plástico adaptado para recolhimento de excretas.

Em ambas situações, foram instalados termômetros de máxima e mínima, cada um nas extremidades dos galpões para que fossem efetuadas três leituras ao dia. Esse procedimento serviu de auxílio no manejo das cortinas laterais durante o estudo.

As condições ambientais, no período experimental, encontraram-se dentro das características da região, não ocorrendo variações climáticas que prejudicassem o desempenho das aves. 


\subsection{DELINEAMENTO E TRATAMENTOS EXPERIMENTAIS}

Foram utilizadas 1080 aves de 22 dias de idade, machos da linhagem Ross. No ensaio I, 900 aves com peso médio inicial de 957,4 g foram distribuídas em delineamento inteiramente casualizado, em esquema fatorial $5 \times 2$. A unidade experimental formada por 30 aves/boxe. $\mathrm{O}$ primeiro fator correspondeu aos níveis de lisina digestível: 0,85; 0,95; 1,05; 1,15; 1,25\% e o segundo fator aos níveis 43 e 253ppm de zinco quelato na forma de carbo-amino-fosfoquelato de zinco.

No ensaio II, sob o mesmo delineamento e três aves por unidade experimental, os tratamentos foram aplicados a 180 frangos, com peso médio inicial de 866,2 g.

Os intervalos considerados na avaliação foram de 22 a 42 dias de idade no ensaio de desempenho e de 22 a 28 dias de idade no ensaio de metabolismo.

As dietas apresentadas na tabela 1 e 2 eram isoenergéticas (3150kcal EM) e as formulações basearam-se nos dados de composição nutricional dos ingredientes apresentados nas tabelas de Rostagno et al. (2005). As rações foram fornecidas ad libitum, tendo como base as quantidades estabelecidas no manual da linhagem, durante a avaliação. As sobras foram pesadas para determinação do consumo de ração médio no período.

As análises bromatológicas das amostras dos alimentos e rações foram realizadas no Laboratório de Bromatologia do Departamento de Nutrição e Produção Animal da Universidade de São Paulo (VNP/USP) segundo os procedimentos descritos por AOAC (1984). As análises de aminoácidos totais das dietas foram realizadas pela empresa Ajinomoto Biolatina Ind. e Com. Ltda. (Tabelas 3 e 4). 
Tabela 1 - Composição das dietas experimentais na fase dos 22 aos 42 dias de idade

\begin{tabular}{|c|c|c|c|c|c|c|}
\hline \multirow{2}{*}{ Ingredientes (\%) } & \multicolumn{5}{|c|}{ Lisina digestível $^{1}(\%)$} & \multirow{2}{*}{$\begin{array}{l}\text { Dieta controle 12-21 } \\
\text { dias de idade }\end{array}$} \\
\hline & 0,85 & 0,95 & 1,05 & 1,15 & 1,25 & \\
\hline Milho moído & 65,90 & 66,13 & 66,60 & 67,00 & 67,00 & 62,27 \\
\hline Farelo de soja & 22,89 & 22,67 & 21,85 & 21,24 & 20,98 & 27,38 \\
\hline Óleo de soja & 2,27 & 2,21 & 2,01 & 1,87 & 1,79 & 1,16 \\
\hline Glúten de milho 60\% & 5,00 & 4,80 & 5,00 & 5,00 & 5,00 & 5,00 \\
\hline L-Lisina $\mathrm{HCl}$ & 0,12 & 0,26 & 0,41 & 0,56 & 0,69 & 0,31 \\
\hline DL-Metionina & 0,05 & 0,13 & 0,21 & 0,29 & 0,37 & 0,20 \\
\hline L-Treonina & - & 0,03 & 0,11 & 0,19 & 0,26 & 0,03 \\
\hline L-Triptofano & - & - & 0,01 & 0,03 & 0,05 & - \\
\hline L-Isoleucina & - & - & - & 0,005 & 0,010 & - \\
\hline L-Valina & - & - & - & 0,007 & 0,013 & - \\
\hline L-Arginina & - & - & - & 0,018 & 0,026 & - \\
\hline Sal Comum & 0,43 & 0,43 & 0,43 & 0,43 & 0,43 & 0,50 \\
\hline Calcário & 1,02 & 1,02 & 1,03 & 1,03 & 1,03 & 1,04 \\
\hline Fosfato bicálcico & 1,67 & 1,67 & 1,68 & 1,68 & 1,69 & 1,79 \\
\hline Cloreto Colina & 0,03 & 0,03 & 0,03 & 0,03 & 0,03 & - \\
\hline Antioxidante & 0,02 & 0,02 & 0,02 & 0,02 & 0,02 & 0,02 \\
\hline $\begin{array}{l}\text { Suplemento Vitamínico e } \\
\text { Mineral }^{2}\end{array}$ & 0,30 & 0,30 & 0,30 & 0,30 & 0,30 & 0,30 \\
\hline $\begin{array}{l}\text { Carboquelato de zinco } \\
\text { e/ou areia lavada }\end{array}$ & 0,30 & 0,30 & 0,31 & 0,30 & 0,31 & - \\
\hline Total & 100,00 & 100,00 & 100,00 & 100,00 & 100,00 & 100,00 \\
\hline \multicolumn{7}{|l|}{ Níveis calculados } \\
\hline $\begin{array}{l}\text { Energia metabolizável } \\
(\mathrm{kcal} / \mathrm{kg})\end{array}$ & 3.150 & 3.150 & 3.150 & 3.150 & 3.150 & 3.050 \\
\hline Proteína bruta (\%) & 19,00 & 19,00 & 19,04 & 19,06 & 19,18 & 21,00 \\
\hline Cálcio (\%) & 0,90 & 0,90 & 0,90 & 0,90 & 0,90 & 0,95 \\
\hline Fósforo disponível (\%) & 0,42 & 0,42 & 0,42 & 0,42 & 0,42 & 0,45 \\
\hline Sódio (\%) & 0,19 & 0,19 & 0,19 & 0,19 & 0,19 & 0,22 \\
\hline Lisina Digestível (\%) & 0,850 & 0,950 & 1,050 & 1,150 & 1,250 & 1,100 \\
\hline $\begin{array}{l}\text { Metionina+Cistina } \\
\text { digestível (\%) }\end{array}$ & 0,637 & 0,712 & 0,787 & 0,862 & 0,937 & 0,825 \\
\hline Treonina digestível (\%) & 0,620 & 0,646 & 0,714 & 0,782 & 0,850 & 0,715 \\
\hline Triptofano digestível (\%) & 0,172 & 0,171 & 0,178 & 0,195 & 0,212 & 0,195 \\
\hline Leucina digestível (\%) & 1,818 & 1,796 & 1,793 & 1,777 & 1,770 & 1,922 \\
\hline Arginina digestível (\%) & 1,034 & 1,024 & 1,004 & 0,986 & 0,978 & 1,161 \\
\hline Valina digestível (\%) & 0,826 & 0,817 & 0,808 & 0,798 & 0,793 & 0,900 \\
\hline Isoleucina digestível (\%) & 0,744 & 0,736 & 0,726 & 0,716 & 0,711 & 0,821 \\
\hline
\end{tabular}

${ }^{1}$ Nível formulado.

${ }^{2}$ Suplementação mineral na forma orgânica (carboquelato) por kg de produto: manganês 18.662ppm; ferro 14.479ppm; zinco $14.452 \mathrm{ppm}$; cobre 2.855ppm; iodo $187 \mathrm{ppm}$; selênio $113 \mathrm{ppm}$. Suplementação viatmínica por $\mathrm{kg}$ de produto: vit. A 3.525.000UI; vit. $\mathrm{D}_{3} 851.250 \mathrm{UI}$; vit. E 4.959ppm; vit. $\mathrm{K}_{3} 600 \mathrm{ppm}$; vit. $\mathrm{B}_{1} 670 \mathrm{ppm}$; vit. $\mathrm{B}_{2} 1.500 \mathrm{ppm}$; vit. $\mathrm{B}_{6} 830 \mathrm{ppm}$; vit. $\mathrm{B}_{12}$ 4ppm; niacina 10.000ppm; ácido pantotênico 3.915ppm; ácido fólico 250ppm; biotina 33ppm; antioxidante 1.400ppm. 
Tabela 2- Valores nutricionais analisados e estimados das dietas fornecidas durante o ensaio I, para avaliação de desempenho, rendimento e composição corporal ${ }^{1}$

\begin{tabular}{|c|c|c|c|c|c|}
\hline \multirow{2}{*}{ Nutrientes (\%) } & \multicolumn{5}{|c|}{ Lisina digestível $^{2}(\%)$} \\
\hline & 0,841 & 0,874 & 0,888 & 1,019 & 1,028 \\
\hline Matéria Seca & 94,79 & 95,16 & 93,63 & 93,73 & 95,79 \\
\hline Proteína Bruta & 21,38 & 22,49 & 22,51 & 22,72 & 23,10 \\
\hline Lisina total & 0,959 & 0,996 & 1,134 & 1,162 & 1,172 \\
\hline Metionina total & 0,366 & 0,343 & 0,469 & 0,538 & 0,495 \\
\hline Cistina total & 0,301 & 0,302 & 0,361 & 0,354 & 0,333 \\
\hline Met + Cist total & 0,667 & 0,645 & 0,830 & 0,892 & 0,828 \\
\hline Treonina total & 0,733 & 0,772 & 0,888 & 0,930 & 0,906 \\
\hline Arginina total & 1,108 & 1,196 & 1,298 & 1,256 & 1,243 \\
\hline Isoleucina total & 0,811 & 0,858 & 0,905 & 0,881 & 0,884 \\
\hline Leucina total & 2,183 & 2,240 & 2,245 & 2,268 & 2,228 \\
\hline Valina total & 0,931 & 0,975 & 1,028 & 1,008 & 0,999 \\
\hline Histidina total & 0,508 & 0,530 & 0,584 & 0,581 & 0,572 \\
\hline Fenilalanina total & 1,054 & 1,098 & 1,148 & 1,133 & 1,142 \\
\hline Alanina total & 1,261 & 1,293 & 1,298 & 1,285 & 1,278 \\
\hline Ácido aspártico total & 1,718 & 1,850 & 1,927 & 1,851 & 1,857 \\
\hline Ácido glutâmico total & 3,614 & 3,807 & 4,093 & 4,060 & 4,045 \\
\hline Glicina total & 0,787 & 0,829 & 0,864 & 0,834 & 0,830 \\
\hline Serina total & 1,001 & 1,066 & 1,072 & 1,050 & 1,046 \\
\hline Tirosina total & 0,757 & 0,776 & 0,784 & 0,796 & 0,780 \\
\hline
\end{tabular}

${ }^{1}$ Análise realizada pela Ajinomoto Biolatina Indústria e Comércio Ltda.

${ }^{2}$ Lisina digestível estimada através do coeficiente de digestibilidade 87,72\%. 
Tabela 3 - Valores nutricionais analisados e estimados das dietas fornecidas durante o ensaio II, para avaliação de balanço de nitrogênio ${ }^{1}$

\begin{tabular}{lccccc}
\hline \hline \multirow{2}{*}{ Nutrientes (\%) } & \multicolumn{5}{c}{ Lisina Digestível $^{2}$ (\%) } \\
\cline { 2 - 6 } Matéria Seca & 0,779 & 0,825 & 0,961 & 1,066 & 1,222 \\
Proteína Bruta & 93,79 & 95,06 & 92,87 & 93,93 & 93,78 \\
Lisina & 20,19 & 20,89 & 21,14 & 20,65 & 21,42 \\
Metionina & 0,888 & 0,941 & 1,096 & 1,215 & 1,393 \\
Cistina & 0,354 & 0,400 & 0,465 & 0,544 & 0,616 \\
Met + Cist & 0,312 & 0,331 & 0,327 & 0,332 & 0,321 \\
Treonina & 0,666 & 0,731 & 0,792 & 0,876 & 0,937 \\
Arginina & 0,755 & 0,778 & 0,800 & 0,856 & 0,959 \\
Isoleucina & 1,112 & 1,141 & 1,132 & 1,118 & 1,174 \\
Leucina & 0,774 & 0,800 & 0,789 & 0,786 & 0,804 \\
Valina & 1,988 & 2,121 & 2,088 & 2,066 & 2,036 \\
Histidina & 0,895 & 0,919 & 0,902 & 0,900 & 0,929 \\
Fenilalanina & 0,523 & 0,543 & 0,526 & 0,529 & 0,528 \\
Alanina & 1,007 & 1,054 & 1,033 & 1,021 & 1,025 \\
Ácido Aspártico & 1,137 & 1,209 & 1,185 & 1,183 & 1,175 \\
Ácido Glutâmico & 1,612 & 1,718 & 1,792 & 1,729 & 1,791 \\
Glicina & 3,572 & 3,778 & 3,815 & 3,723 & 3,743 \\
Serina & 0,744 & 0,771 & 0,775 & 0,754 & 0,775 \\
Tirosina & 0,926 & 0,991 & 0,980 & 0,952 & 0,961 \\
\hline \hline Ánise & 0,715 & 0,710 & 0,704 & 0,722 & 0,725 \\
\hline
\end{tabular}

${ }^{1}$ Análise realizada pela Ajinomoto Biolatina Indústria e Comércio Ltda.

${ }^{2}$ Lisina digestível estimada através do coeficiente de digestibilidade 87,72\%.

\subsection{PROCEDIMENTOS PARA DETERMINAÇÃO DA COMPOSIÇÃO QUÍMICA CORPORAL}

No início do experimento, foram abatidas 10 aves aleatoriamente escolhidas para determinação da composição química das frações vísceras-sangue e carcaça. Os dados obtidos nesta etapa foram definidos como iniciais ou do abate comparativo. A partir destas informações, em suas respectivas frações, foram determinados os acréscimos e as deposições diárias dos componentes químicos corporais ao final do período experimental. 
No $42^{\circ}$ dia, uma ave de cada unidade experimental foi abatida para determinação da composição química das frações e corpo vazio e as taxas de deposição de nutrientes corporais. Elas foram escolhidas de acordo com o peso médio final da parcela.

Nos abates, adotou-se o método de sangria. O sangue foi coletado em sacos plásticos. As vísceras foram retiradas, lavadas de seus conteúdos e adicionadas ao sangue. Após a identificação o material foi pesado e congelado até a primeira etapa do processamento. A carcaça, do mesmo modo, depois de identificada foi pesada e congelada.

Consideraram-se como vísceras: trato digestório vazio, órgãos reprodutores, coração, fígado, baço, pulmão, glândulas anexas e gordura adjacente (TRINDADE NETO et al., 2004). Na determinação da composição química das frações corporais, para a carcaça incluiu-se cabeça, penas e pés, sem vísceras e sangue. Já o corpo vazio foi definido como a diferença entre o peso vivo em jejum e o conteúdo gastrintestinal (SUSENBETH; KEITEL, 1988).

\subsection{PROCESSAMENTO DAS FRAÇÕES CORPORAIS, AMOSTRAGEM E ANÁLISES}

O processamento e preparo das amostras foi realizado no Laboratório de Carnes do Instituto de Zootecnia em Nova Odessa, São Paulo.

Após congelamento sangue e vísceras e carcaça das aves amostradas foram reduzidos ao estado pastoso através de um moedor de carne. Retiraram-se quatro amostras da fração sangue e vísceras e da fração carcaça. Estas amostras foram armazenadas em placas de Petri para serem liofilizadas posteriormente (LEME et al. 1994; SHIELDS et al. 1983).

A liofilização ocorreu em equipamento modelo Stokes sistema de vácuo a $3 \mathrm{~mm} \mathrm{Hg}$ de pressão máxima em temperatura inicial de menos $15{ }^{\circ} \mathrm{C}$ e final de $10{ }^{\circ} \mathrm{C}$ cuja secagem deuse por sublimação. As amostras liofilizadas foram moídas separadamente com gelo seco em liquidificador para posteriores análises em duplicatas no Laboratório de Bromatologia da FMVZ-USP Pirassununga.

Na composição química, foram considerados os conteúdos: água, proteína, lipídeo e matéria mineral. Os valores foram expressos em gramas ou como porcentagem na fração vísceras e sangue, na fração carcaça e no corpo vazio. Os dados foram expressos em matéria natural, corrigidos pela matéria seca liofilizada. A partir da composição química corporal, foram determinadas as taxas de deposição de água, protéica, lipídica e mineral na carcaça e no corpo vazio ao final do período experimental (42 dias de idade). 
A matéria seca considerada foi a liofilizada, porém a correção dos demais componentes químicos analisados foi realizada através da matéria seca em estufa $105^{\circ} \mathrm{C}$, evitando-se erros provenientes da reabsorção de água durante o processamento das amostras. A partir da matéria seca liofilizada, foram determinadas: matéria seca à $105^{\circ} \mathrm{C}$, proteína bruta, extrato etéreo e matéria mineral, segundo AOAC (1984).

A extração do extrato etéreo ocorreu em aparelho Soxhlet com auxílio de éter etílico durante 6 horas. A proteína bruta foi estimada a partir da análise de nitrogênio em Macro Kjehdal utilizando a mostra desengordurada proveniente da extração lipídica. A matéria mineral foi determinada com a queima das amostras em mufla, $600^{\circ} \mathrm{C}$ por 6 horas.

\subsection{BALANÇO DE NITROGÊNIO}

O período de coleta das excretas para determinação do balanço de nitrogênio foi de 3 dias, após uma adaptação de 4 dias das aves à dieta. As coletas foram diárias e eram pesadas e congeladas a menos $10^{\circ} \mathrm{C}$ até serem preparadas para análises. Nas rações fornecidas e nas excretas, foram determinados matéria seca a $65^{\circ} \mathrm{C}$ e $105^{\circ} \mathrm{C}$, nitrogênio em Micro Kjehdal e energia bruta através de combustão em calorímetro.

\subsection{COEFICIENTE DE DIGESTIBILIDADE}

Uma vez que os valores de aminoácidos são expressos como totais, aplicou-se o índice de digestibilidade para corrigir os valores estimados de lisina pelas equações de regressão. Esse fator de correção (87,72\%) foi obtido com base na média ponderal dos coeficientes de digestibilidade propostos por Rostagno et al. (2005) para lisina total, conforme a inclusão do milho, farelo de soja e do glúten nas dietas experimentais.

Cálculo: Lisina total analisada/lisina digestível formulada mais próxima do valor estimado pela equação; o valor obtido é multiplicado pelo estimado na equação; e o novo valor é multiplicado pelo índice de digestibilidade; o valor final é o estimado corrigido. 


\subsection{VARIÁVEIS AVALIADAS E ANÁLISE ESTATÍSTICA}

As variáveis consideradas na avaliação do desempenho foram: peso final médio, ganho em peso médio, ganho em peso relativo, consumo de ração médio e conversão alimentar. Para efeito de correção do consumo de ração médio os dados obtidos foram corrigidos de acordo com a mortalidade dentro da unidade experimental.

A análise estatística dos dados foi realizada a partir dos níveis de lisina total encontrados na análise de aminoácidos. A lisina digestível estimada foi resultante da multiplicação da lisina total pelo fator de correção 87,72\%, baseado na média ponderal dos coeficientes de digestibilidade propostos por Rostagno et al. (2005), conforme a inclusão dos ingredientes na dieta.

$\mathrm{Na}$ análise estatística foi considerado peso médio inicial para avaliar a casualização dentro do delineamento aplicado.

Na composição química corporal, foram consideradas as concentrações percentuais de água, proteína bruta, extrato etéreo e matéria mineral do sangue e vísceras, carcaça e corpo vazio. A partir da composição, foram determinadas as taxas de deposição de água, proteína, lipídeo e mineral na carcaça e corpo vazio; e calculadas as relações proteína: água e proteína: lipídeo.

No estudo de digestibilidade foram considerados a ingestão e a retenção do nitrogênio, bem como a fração metabolizável da energia, a relação energia bruta: metabolizável e balanço energético.

As análises estatísticas das variáveis experimentais foram realizadas através do pacote computacional SAS (2004) através de General Linear Models (PROC GLM). No fator lisina digestível adotou-se a regressão polinomial e para o fator zinco o Teste F. O modelo estatístico adotado foi:

$$
Y_{i j}=\mu+A_{i}+B_{j}+A_{i} B_{j}+e_{i j} \text { sendo: }
$$

$\mathrm{Y}_{\mathrm{ij}}=$ constante associada a todas observações;

$\mu$ = média geral da variável

$\mathrm{A}_{\mathrm{i}}=$ efeito do nível de lisina $\mathrm{i}$, sendo $\mathrm{i}=1234$ e 5;

$B_{j}=$ efeito da suplementação de zinco quelato $\mathrm{j}$, sendo $\mathrm{j}=1$ e 2 ;

$\mathrm{A}_{\mathrm{i}} \mathrm{B}_{\mathrm{j}}=$ efeito da interação do nível de lisina e suplementação de zinco quelato;

$\mathrm{e}_{\mathrm{ij}}=$ erro aleatório associado a cada observação. 


\section{RESULTADOS E DISCUSSÃO}

No ensaio I a temperatura média foi $24^{\circ} \mathrm{C}$ e umidade relativa média do ar foi $66 \%$. No ensaio II as respectivas médias foram $26^{\circ} \mathrm{C}$ e $88 \%$. Nos períodos correspondentes, as temperaturas do interior dos galpões variaram de 23 a $29{ }^{\circ} \mathrm{C}$ e 24 a $31{ }^{\circ} \mathrm{C}$ nos ensaios I e II, respectivamente.

O nível de lisina digestível, recomendado para esta fase é de 1,073\% ou de 0,950\% segundo Rostagno (2005) e Agroceres (2004), respectivamente e o de zinco de 40ppm segundo NRC (1994).

\subsection{DESEMPENHO}

Os resultados de desempenho dos frangos dos 22 aos 42 dias de idade estão apresentados na tabela 4. Constatou-se interação $(P<0,05)$ dos níveis de lisina digestível e zinco nas variáveis peso médio final, ganho em peso médio e conversão alimentar.

O aumento da concentração de lisina nas dietas com 43 ppm de zinco quelato favoreceu o desempenho dos frangos até o nível 1,06\% de lisina total (0,93\% de lisina digestível) para peso médio final segundo a equação $\mathrm{Y}=-10220,56559+27713,34559 \mathrm{X}-$ $14837,05706 \mathrm{X} 2, \mathrm{r}^{2}=0,20$ e para o ganho em peso médio, conforme figura 2 . Apesar das equações serem significativas $(P<0,05)$ os coeficientes de determinação são considerados baixos para estas características. Baseando-se no nível de precisão das informações $\left(r^{2}\right)$ o tratamento mais indicado foi o nível de 0,995\% de lisina digestível. Nessas variáveis, o nível estimado de lisina total correspondeu à ingestão de 34,2 g no período (1,63g /dia) quando os frangos ganharam 1,740 $\mathrm{g}$ e foram abatidos aos 2,626 $\mathrm{g}$ de peso vivo.

Na concentração de 253 ppm do zinco quelato o aumento do nível de lisina digestível coincidiu com o acréscimo $(\mathrm{P}<0,05)$ linear do peso médio final $(\mathrm{Y}=2227,267401+$ $\left.428,133206 \mathrm{X}, \mathrm{r}^{2}=0,48\right)$ e do ganho em peso médio dos frangos no período de 22 a 42 dias de idade segundo a figura 2. Estas respostas sugerem a necessidade de lisina em nível igual ou superior ao maior nível estudado. As dietas com maior concentração de zinco, embora caracterizem efetividade do acréscimo de lisina, não apresentam diferenças significativas para as médias do fator. Na dieta de menor concentração (43 ppm) de zinco, houve efeito mais 
pronunciado na maioria dos níveis de aminoácido aplicados. Burrel et al. (2004) e Kidd et al. (1992) não constataram efeito do zinco quelato estudando níveis que variaram de 80 a 181ppm em frangos de corte de 1 a 35 dias de idade.

Ao considerar nível zinco dentro do fator lisina, a maior diferença no peso médio e ganho em peso ocorreu entre os frangos que receberam dietas com 1,028\% de lisina digestível. Nesse nível do aminoácido digestível, o melhor desempenho ocorreu nas aves que receberam a dieta que continha 253 ppm de zinco. Destaca-se, todavia, que o maior ganho ocorreu sob o nível de 0,995\% de lisina digestível e, numericamente, em favor do nível 43 ppm de zinco. Respostas essas, também indicadas nas variáveis consumo e conversão alimentar.

Valor estimado de lisina total (1,06\%) no presente estudo, foi um pouco acima do nível de 1,03\% proposto por Barboza (2000) para machos da linhagem Ross dos 22 aos 42 dias de idade. Foi semelhante a observação de Borges et al. (2002) para machos da linhagem Avian Farms (1,05\%) na mesma fase do crescimento, mas abaixo da orientação de 1,08\% feita pela Agroceres (2004) para a linhagem Ross no Brasil. Todos esses níveis, contudo, estão abaixo ao 1,22\% de lisina total proposto por Rostagno et al. (2005). Na tabela de exigência nutricional de Rostagno et al. (2005) as exigências são propostas segundo fase, sexo e desempenho (inferior, médio e superior) independentemente da linhagem utilizada. As exigências nutricionais, no entanto, podem variar de acordo com a linhagem utilizada. Segundo Sterling et al. (2006) Rostagno e Pack, (1995) e Barboza (2000) linhagens de frangos de cortes respondem de maneira diferenciada ao nível de lisina e proteína bruta da dieta. Em casos de excesso de aminoácidos na ração, além do alto custo da formulação, ocorrem também problemas no desempenho produtivo (ARAÚJO et al., 2002; CHUNG; BAKER, 1992). 


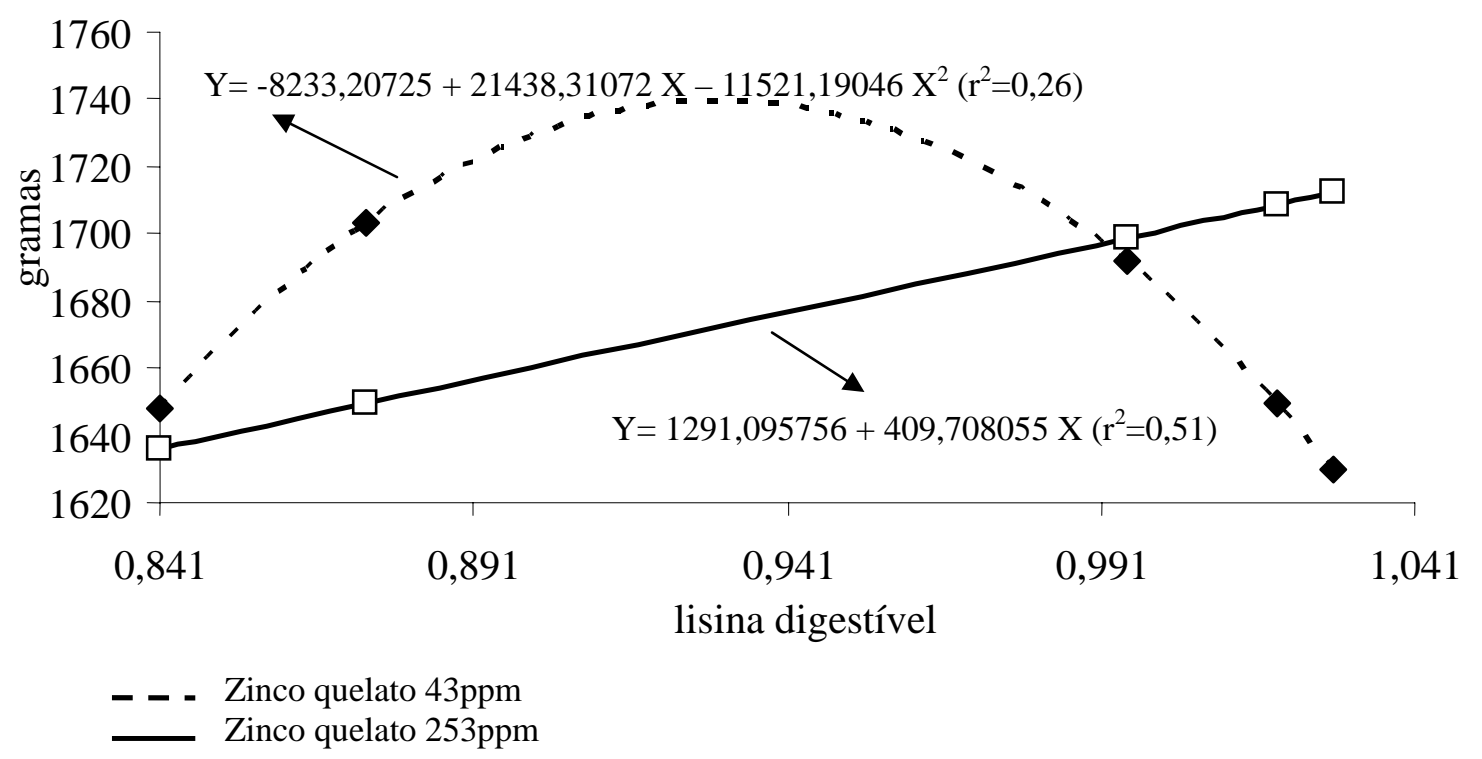

Figura 2 - Ganho em peso estimado, em função do nível de lisina digestível e zinco quelato na dieta

Embora os dados conversão alimentar (Tabela 4) indiquem efeito da utilização dos nutrientes das dietas, favorável a maior suplementação de zinco, como foi observado no ganho em peso e peso final, cabem as mesmas considerações de que os resultados do nível 0,995\% foram superiores em relação aos outros níveis utilizados. A diferença apresentada no nível 1,028\% decorreu portanto, do pior desempenho e consumo dos frangos alimentados com a dieta com 43ppm.

O ganho em peso relativo (porcentagem de ganho em peso relacionado ao peso no início do experimento) e o consumo de ração médio não tiveram variações significativas com o acréscimo de lisina digestível ou de zinco quelato na dieta. Pôde-se observar, no entanto, que a variação numérica nessas variáveis confirma os efeitos das observações destacadas anteriormente de que o nível de lisina digestível 0,995\% é o mais indicado, independentemente da concentração de zinco quelato. No ganho em peso relativo, contatou-se a maior necessidade de lisina $(1,028 \%)$ quando a concentração de zinco foi mais elevada (253ppm). Na dieta com menor inclusão (43ppm) de zinco os frangos tiveram desempenho semelhante quando o teor de lisina foi de 0,995\%.

Mesmo que o consumo de ração não tenha sido influenciado pelos tratamentos, pôdese observar que o aumento da concentração de lisina na dieta acarreta diminuição no consumo. Na dieta com 43ppm de zinco, a variação numérica indica redução mais pronunciada da ingestão de alimentos pelos frangos de corte. Dados de consumo em função 
dos níveis de lisina digestível, todavia são controversos. Borges et al. (2002b) Valério et al. (2003) e Barboza et al. (2000) utilizando aves de idade semelhantes a este estudo, mas de linhagens diversas, não observaram efeito do nível de lisina sobre o consumo. Outros autores verificaram que o aumento do nível de lisina na dieta fez com que os frangos diminuíssem o consumo de ração (CONHALATO et al.,1999; FATUFE et al., 2004; SKLAN; NOY, 2004) . No presente estudo, além do efeito mais relevante do nível de lisina, independentemente do nível de zinco, pôde-se constatar que o aumento da concentração dos aminoácidos, acima de 0,995\%, coincidiu com a redução numérica do consumo. Essa redução também, coincide com as demais variáveis do desempenho para os níveis abaixo e acima do nível supracitado.

Em relação à ação conjunta de zinco e aminoácidos, Cheng et al. (1998) ao estudarem diferentes níveis e fontes de zinco associados a níveis de lisina em suínos, também observaram efeito da interação de lisina e zinco. No presente estudo, apesar da melhor $(\mathrm{P}<0,05)$ conversão alimentar coincidir com o maior nível de lisina digestível e maior nível de zinco dietéticos, a resposta não coincide com o melhor desempenho corporal dos frangos, observados para a dieta com 0,995\% de lisina digestível no menor nível de zinco (43ppm).

Devido ao papel do zinco no sistema imune, além dos benefícios no trato gastrintestinal, esperava-se que aumento da inclusão de zinco na dieta teria alguma relação com a mortalidade dos frangos. Essa variável, porém não foi influenciada pelos tratamentos aplicados. Resultado semelhante ao de Burrel et al. (2004) utilizando dieta com 80ppm de zinco para frangos de corte machos Coob criados até os 45 dias de idade. 
Tabela 4 - Desempenho de frangos de corte em função do nível nutricional

\begin{tabular}{|c|c|c|c|c|c|c|c|c|}
\hline \multirow{2}{*}{$\begin{array}{l}\text { Variáveis } \\
\text { avaliadas }\end{array}$} & \multirow{2}{*}{ Zinco } & \multicolumn{6}{|c|}{ Lisina digestível (\%) } & \multirow{2}{*}{ CV $(\%)$} \\
\hline & & 0,841 & 0,874 & 0,995 & 1,019 & 1,028 & média & \\
\hline \multirow{4}{*}{$\begin{array}{l}\text { Peso médio } \\
\text { inicial (g) }\end{array}$} & 43ppm & 943 & 967 & 968 & 973 & 954 & 961 & 3,75 \\
\hline & 253ppm & 944 & 958 & 970 & 960 & 936 & 954 & 3,59 \\
\hline & média & 944 & 962 & 969 & 967 & 945 & 957 & \\
\hline & CV (\%) & 2,23 & 2,13 & 3,52 & 2,77 & 6,32 & & \\
\hline \multirow{4}{*}{$\begin{array}{l}{ }^{1} \text { Peso médio } \\
\text { final }(g)\end{array}$} & 43ppm** & $2642^{\mathrm{a}}$ & $2591^{\mathrm{a}}$ & $2721^{\mathrm{a}}$ & $2675^{\mathrm{a}}$ & $2496^{\mathrm{b}}$ & 2625 & 3,48 \\
\hline & 253ppm* & $2610^{\mathrm{a}}$ & $2562^{\mathrm{a}}$ & $2709^{a}$ & $2652^{\mathrm{a}}$ & $2638^{a}$ & 2634 & 2,55 \\
\hline & média & 2626 & 2577 & 2715 & 2664 & 2568 & 2634 & \\
\hline & $\mathrm{CV}(\%)$ & 1,74 & 2,41 & 1,00 & 1,00 & 4,01 & & \\
\hline \multirow{4}{*}{$\begin{array}{l}{ }^{1} \text { Ganho em } \\
\text { peso médio } \\
\text { (g) }\end{array}$} & 43ppm** & $1699^{a}$ & $1625^{a}$ & $1754^{\mathrm{a}}$ & $1702^{\mathrm{a}}$ & $1543^{b}$ & 1664 & 5,09 \\
\hline & 253ppm* & $1666^{\mathrm{a}}$ & $1605^{\mathrm{a}}$ & $1740^{\mathrm{a}}$ & $1692^{\mathrm{a}}$ & $1703^{\mathrm{a}}$ & 1681 & 3,25 \\
\hline & média & 1682 & 1615 & 1746 & 1697 & 1623 & 1681 & \\
\hline & CV (\%) & 3,00 & 3,51 & 1,26 & 0,81 & 5,51 & & \\
\hline \multirow{4}{*}{$\begin{array}{l}\text { Ganho em } \\
\text { peso } \\
\text { relativo (g) }\end{array}$} & 43ppm & 180,4 & 168,0 & 181,6 & 175,1 & 162,0 & 173,4 & 6,46 \\
\hline & 253ppm & 176,4 & 167,7 & 179,4 & 176,2 & 182,5 & 176,5 & 4,69 \\
\hline & média & 178,4 & 167,9 & 180,5 & 175,7 & 172,3 & 174,9 & \\
\hline & CV (\%) & 4,47 & 3,93 & 4,53 & 3,09 & 8,85 & & \\
\hline \multirow{4}{*}{$\begin{array}{l}\text { Consumo de } \\
\text { ração médio } \\
\text { (g) }\end{array}$} & 43ppm & 3294 & 3299 & 3355 & 3273 & 3162 & 3277 & 2,56 \\
\hline & 253ppm & 3285 & 3131 & 3356 & 3325 & 3231 & 3266 & 3,48 \\
\hline & média & 3289 & 3215 & 3356 & 3299 & 3197 & 3271 & \\
\hline & CV (\%) & 1,34 & 4,54 & 1,08 & 2,04 & 2,56 & & \\
\hline \multirow{4}{*}{$\begin{array}{l}\text { Conversão } \\
\text { alimentar } \\
\text { (g) }\end{array}$} & 43ppm & $1,94^{\mathrm{a}}$ & $2,03^{\mathrm{a}}$ & $1,91^{\mathrm{a}}$ & $1,92^{\mathrm{a}}$ & $2,05^{\mathrm{a}}$ & 1,97 & 3,61 \\
\hline & 253ppm & $1,97^{\mathrm{a}}$ & $1,95^{\mathrm{b}}$ & $1,93^{\mathrm{a}}$ & $1,97^{\mathrm{a}}$ & $1,90^{\mathrm{b}}$ & 1,94 & 2,30 \\
\hline & média & 1,96 & 1,99 & 1,92 & 1,95 & 1,98 & 1,96 & \\
\hline & CV (\%) & 2,21 & 2,54 & 1,89 & 2,71 & 4,74 & & \\
\hline
\end{tabular}

*Equação linear significativa; **Equação quadrática significativa $(\mathrm{P}<0,05)$.

${ }^{1}$ Interação nível de zinco quelato e nível de lisina digestível $(\mathrm{P}<0,05)$.

Letras diferentes na mesma coluna diferem entre si para Teste $\mathrm{F}(\mathrm{P}<0,05)$.

\subsection{RENDIMENTO}

O peso vivo e os rendimentos de cortes estão apresentados na Tabela 5.

Não houve interação e efeito isolado do nível de zinco quelato nas variáveis de rendimento de cortes. 
Em resposta ao aumento de lisina digestível na dieta, obteve-se efeito linear crescente em peso vivo, porcentagem de peito e porcentagem de coxa e sobrecoxa $(\mathrm{P}<0,05)$ segundo as equações: $Y=2328,412838+386,245352 X\left(r^{2}=0,20\right), Y=17,44459198+7,5959022 X$ $\left(r^{2}=0,77\right)$ e $Y=26,04887496-3,31953783 X\left(r^{2}=0,84\right)$ respectivamente. Esses resultados sugerem que a exigência para o rendimento de cortes é igual ou superior ao maior nível de lisina utilizado neste experimento (1,028\%). Efeito semelhante foi encontrado por Borges et al. (2002) e Eits et al. (2003) confirmando as observações de Kidd et al. (1997) de que a exigência para o máximo rendimento de peito está acima da demanda considerada para o máximo crescimento. Neste caso, ficou caracterizado o direcionamento da lisina para o crescimento muscular, constatado pela maior precisão estatística, expressa no coeficiente de determinação.

Ainda que as variações sejam numéricas, os valores porcentuais de fígado indicam que o aumento da concentração dietética de aminoácidos coincidiu com aumento das atividades metabólicas no fígado, sugerindo provável redução da lipogênese. Em casos de excesso, os aminoácidos na dieta fazem com que o animal diminua a ingestão. $\mathrm{O}$ aumento do fígado em resposta ao excesso de aminoácidos na dieta também foi observado por Leeson e Zubair (1997) e Swatson et al. (2002) quando estudaram níveis de proteína bruta e aminoácidos na dieta para frangos de corte.

Os aminoácidos não utilizados no metabolismo protéico aumentam a atividade hepática e renal, pois são desaminados até ácido úrico, subindo o nível desse composto no sangue. Além disso, quando os aminoácidos excederem as demandas nutricionais, parte da estrutura química não utilizada fornecerá energia para a formação de gorduras que serão depositadas no organismo da ave.

Na presença de 253ppm de zinco, sugere-se maior eficiência na utilização de lisina, com base no menor peso do fígado, indicando, provavelmente, menor intensidade das atividades hepáticas. Essa observação é indicada pela semelhança entre os resultados médios do peso vivo, carcaça e os cortes considerados, sob os dois níveis de zinco. 
Tabela 5 - Rendimento de cortes em função do nível nutricional

\begin{tabular}{|c|c|c|c|c|c|c|c|c|}
\hline \multirow{2}{*}{$\begin{array}{l}\text { Variáveis } \\
\text { avaliadas }\end{array}$} & \multirow{2}{*}{ Zinco } & \multicolumn{6}{|c|}{ Lisina digestível (\%) } & \multirow{2}{*}{ CV (\%) } \\
\hline & & 0,841 & 0,874 & 0,995 & 1,019 & 1,028 & média & \\
\hline \multirow{4}{*}{$\begin{array}{l}\text { Peso vivo } \\
\text { (g) }\end{array}$} & 43ppm* & 2730 & 2594 & 2832 & 2719 & 2613 & 2698 & 4,02 \\
\hline & 253ppm & 2672 & 2585 & 2766 & 2713 & 2734 & 2694 & 3,50 \\
\hline & média & 2701 & 2590 & 2799 & 2716 & 2674 & 2696 & \\
\hline & CV (\%) & 2,06 & 3,65 & 2,06 & 1,87 & 4,17 & & \\
\hline \multirow{4}{*}{$\begin{array}{l}\text { Gordura } \\
\text { abdominal } \\
(\%)\end{array}$} & 43ppm & 1,70 & 2,02 & 1,69 & 1,40 & 1,69 & 1,70 & 16,32 \\
\hline & 253ppm & 1,84 & 1,61 & 1,89 & 1,81 & 1,51 & 1,73 & 15,31 \\
\hline & média & 1,77 & 1,82 & 1,79 & 1,61 & 1,60 & 1,72 & \\
\hline & $\mathrm{CV}(\%)$ & 12,35 & 20,24 & 12,94 & 17,88 & 12,87 & & \\
\hline \multirow{4}{*}{ Fígado (\%) } & 43ppm & 2,19 & 2,09 & 2,17 & 2,16 & 2,22 & 2,17 & 5,77 \\
\hline & 253ppm & 2,03 & 2,12 & 2,12 & 2,12 & 2,05 & 2,09 & 7,73 \\
\hline & média & 2,11 & 2,11 & 2,15 & 2,14 & 2,14 & 2,13 & \\
\hline & CV (\%) & 7,40 & 9,17 & 3,05 & 8,85 & 7,05 & & \\
\hline \multirow{4}{*}{$\begin{array}{l}\text { *Coxa e } \\
\text { sobrecoxa } \\
(\%)\end{array}$} & 43ppm & 23,20 & 23,40 & 22,36 & 22,74 & 22,52 & 22,84 & 2,21 \\
\hline & 253ppm & 23,30 & 22,98 & 22,70 & 22,66 & 23,01 & 22,93 & 3,32 \\
\hline & média & 23,25 & 23,19 & 22,53 & 22,70 & 22,77 & 22,89 & \\
\hline & CV (\%) & 3,40 & 1,76 & 1,86 & 3,40 & 2,44 & & \\
\hline \multirow{4}{*}{ Asa (\%) } & 43ppm & 8,31 & 8,48 & 8,11 & 8,30 & 8,10 & 8,26 & 2,87 \\
\hline & 253ppm & 8,31 & 8,33 & 8,21 & 8,27 & 8,41 & 8,31 & 2,27 \\
\hline & média & 8,31 & 8,41 & 8,16 & 8,29 & 8,26 & 8,28 & \\
\hline & CV (\%) & 2,76 & 2,35 & 2,47 & 1,55 & 3,23 & & \\
\hline \multirow{4}{*}{ *Peito (\%) } & 43ppm & 23,70 & 23,48 & 25,47 & 25,91 & 24,89 & 24,69 & 4,70 \\
\hline & 253ppm & 24,34 & 24,02 & 25,41 & 24,65 & 24,81 & 24,65 & 3,27 \\
\hline & média & 24,02 & 23,75 & 25,44 & 25,28 & 24,85 & 24,67 & \\
\hline & CV (\%) & 3,34 & 3,35 & 2,67 & 3,72 & 2,00 & & \\
\hline \multirow{4}{*}{ Carcaça (\%) } & 43ppm & 80,68 & 80,01 & 80,41 & 80,94 & 80,20 & 80,45 & 0,82 \\
\hline & 253ppm & 81,17 & 80,75 & 80,77 & 80,75 & 81,13 & 80,91 & 0,68 \\
\hline & média & 80,93 & 80,38 & 80,59 & 80,85 & 80,67 & 80,68 & \\
\hline & CV (\%) & 0,98 & 0,94 & 0,62 & 0,65 & 0,83 & & \\
\hline \multirow{4}{*}{$\begin{array}{l}\text { Carcaça } \\
\text { Shiller (\%) }\end{array}$} & 43ppm & 81,09 & 80,39 & 80,78 & 81,89 & 80,80 & 80,99 & 1,13 \\
\hline & 253ppm & 81,82 & 81,23 & 81,04 & 81,16 & 81,64 & 81,38 & 0,80 \\
\hline & média & 81,46 & 80,81 & 80,91 & 81,53 & 81,22 & 81,18 & \\
\hline & CV (\%) & 1,22 & 1,19 & 0,69 & 1,05 & 0,68 & & \\
\hline
\end{tabular}

*Regressão linear significativa $(\mathrm{P}<0,05)$. 


\subsection{COMPOSIÇÃO QUÍMICA CORPORAL}

Os resultados de composição química corporal dos frangos ao final do período experimental encontram-se na tabela 6.

Constatou-se interação $(\mathrm{P}<0,05)$ do nível de lisina digestível e zinco nas variáveis porcentuais de água e extrato etéreo do corpo vazio.

Apesar de não haver efeito significativo no peso vivo em jejum e peso do corpo vazio, as variações numéricas reafirmam dados referentes ao desempenho, onde os melhores resultados ocorreram sob o nível 0,995\% de lisina digestível na dieta, independentemente do nível de zinco utilizado.

No corpo vazio a análise estatística indicou acréscimo linear do teor de água à medida que houve aumento na concentração de lisina nas dietas que continham 43 ppm do zinco quelato, segundo equação $Y=58,43912441+9,45645953 X\left(r^{2}=0,46\right)$. Há que destacar, no entanto, a baixa precisão dessa informação como indica o coeficiente de determinação obtido. Sob a mesma concentração dietética de zinco (43ppm) pôde-se constatar redução linear do percentual de extrato etéreo corporal dos frangos ao final do período estudado, seguindo equação $Y=27,60553205$ - 14,92137767 X $\left(r^{2}=0,65\right)$. Essa segunda observação, com 65\% de precisão, sugere $(\mathrm{P}<0,05)$ aumento na eficiência da síntese protéica e direcionamento dos aminoácidos para acúmulo de massa muscular. Silva et al. (2003) e Pesti e Bakalli (1997) observaram que o aumento do nível dietético de lisina digestível acresce água no peso do animal e diminui a participação do extrato etéreo. A diminuição do lipídeo corporal, em resposta ao excesso de aminoácidos, também foi observada por Bartov (1996) este efeito foi associado ao aumento no incremento calórico envolvido na degradação do excesso de nitrogênio até ácido úrico.

Na dieta com 43 ppm ao aumento da concentração de lisina digestível propiciou efeito linear para a composição de água e extrato etéreo no corpo vazio, segundo as equações $\mathrm{Y}=$ $58,43912441+9,45645953 X\left(r^{2}=0,46\right)$ e $Y=27,60553205-14,92137767 X\left(r^{2}=0,65\right)$ respectivamente. Na variável porcentual de água do corpo vazio, o maior $(\mathrm{P}<0,05)$ acúmulo ficou caracterizado nos animais que receberam 43 ppm do zinco, nas dietas com 0,995 e 1,019\% de lisina digestível. Simultaneamente, pôde-se observar que essas aves tiveram menor $(\mathrm{P}<0,05)$ acréscimo de gordura, sob as mesmas dietas. Nesses níveis do aminoácido, sugere-se o melhor desempenho corporal das aves, uma vez que o aumento da água corporal coincide com o aumento da proteína e à diminuição do acúmulo de gordura. 
Na matéria mineral, observou-se resposta quadrática para o aumento do nível dietético de lisina, segundo a equação $Y=-57,3027502+131,0632839$ X -70,3536622 X2 $\left(r^{2}=0,77\right)$. O nível digestível do aminoácido estimado como ótimo é de 0,931\% na dieta. O efeito de lisina nessa variável, como ocorreu anteriormente, ratifica o melhor desempenho dos frangos que receberam as dietas com 0,995 e 1,019\% de lisina e 43 ppm de zinco. Nos níveis citados e no ponto ótimo estimado para o aminoácido, a porcentagem de matéria mineral também coincide com o maior desempenho corporal, como também pôde ser verificado na variável relação proteína:extrato etéreo.

Tabela 6 - Composição química do corpo vazio na matéria natural em função do nível nutricional

\begin{tabular}{|c|c|c|c|c|c|c|c|c|}
\hline \multirow{2}{*}{$\begin{array}{l}\text { Variáveis } \\
\text { avaliadas }\end{array}$} & \multirow[t]{2}{*}{ Zinco } & \multicolumn{6}{|c|}{ Lisina digestível (\%) } & \multirow[t]{2}{*}{ CV (\%) } \\
\hline & & 0,841 & 0,874 & 0,995 & 1,019 & 1,028 & média & \\
\hline \multirow{4}{*}{$\begin{array}{l}\text { Peso vivo em } \\
\text { jejum (g) }\end{array}$} & 43ppm & 2623 & 2567 & 2712 & 2637 & 2507 & 2609 & 3,66 \\
\hline & 253ppm & 2640 & 2510 & 2770 & 2668 & 2662 & 2650 & 4,27 \\
\hline & média & 2632 & 2538 & 2741 & 2653 & 2584 & 2630 & \\
\hline & CV (\%) & 0,89 & 3,03 & 3,10 & 3,19 & 4,76 & & \\
\hline \multirow{4}{*}{$\begin{array}{l}\text { Peso vivo } \\
\text { reconstituído } \\
\text { (g) }\end{array}$} & 43ppm & 2574 & 2513 & 2627 & 2518 & 2450 & 2536 & 3,91 \\
\hline & 253ppm & 2564 & 2443 & 2704 & 2608 & 2614 & 2587 & 4,55 \\
\hline & média & 2569 & 2478 & 2665 & 2563 & 2532 & 2561 & \\
\hline & CV (\%) & 1,24 & 3,13 & 3,84 & 4,45 & 5,16 & & \\
\hline \multirow[t]{4}{*}{${ }^{1}$ Água (\%) } & 43ppm* & $67,39^{\mathrm{a}}$ & $65,40^{b}$ & $68,23^{\mathrm{a}}$ & $68,46^{\mathrm{a}}$ & $67,73^{\mathrm{a}}$ & 67,44 & 1,90 \\
\hline & 253ppm & $66,28^{\mathrm{a}}$ & $67,45^{\mathrm{a}}$ & $66,62^{\mathrm{b}}$ & $66,91^{\mathrm{b}}$ & $67,75^{\mathrm{a}}$ & 67,00 & 1,58 \\
\hline & média & 66,84 & 66,43 & 67,43 & 67,69 & 67,74 & & \\
\hline & CV (\%) & 1,69 & 2,30 & 1,39 & 1,54 & 1,39 & & \\
\hline \multirow{4}{*}{$\begin{array}{l}{ }^{1} \text { Extrato } \\
\text { etéreo (\%) }\end{array}$} & 43ppm* & $14,13^{\mathrm{a}}$ & $15,81^{\mathrm{a}}$ & $12,36^{\mathrm{b}}$ & $11,71^{b}$ & $13,03^{\mathrm{a}}$ & 13,41 & 12,68 \\
\hline & 253ppm & $15,17^{\mathrm{a}}$ & $13,21^{b}$ & $14,5^{\mathrm{a}}$ & $14,47^{\mathrm{a}}$ & $12,70^{\mathrm{a}}$ & 14,01 & 10,12 \\
\hline & média & 14,65 & 14,51 & 13,43 & 13,09 & 12,87 & 13,71 & \\
\hline & CV (\%) & 7,06 & 14,45 & 9,49 & 13,29 & 7,33 & & \\
\hline \multirow{4}{*}{$\begin{array}{l}\text { Proteína } \\
\text { bruta (\%) }\end{array}$} & 43ppm & 15,30 & 15,21 & 15,85 & 16,67 & 16,17 & 15,84 & 5,51 \\
\hline & 253ppm & 15,27 & 16,13 & 15,36 & 15,28 & 16,68 & 15,74 & 5,84 \\
\hline & média & 15,29 & 15,67 & 15,61 & 15,98 & 16,43 & 15,79 & \\
\hline & CV (\%) & 5,39 & 5,73 & 3,43 & 6,71 & 5,12 & & \\
\hline \multirow{4}{*}{$\begin{array}{l}* * \text { Matéria } \\
\text { mineral (\%) }\end{array}$} & 43ppm & 3,18 & 3,58 & 3,56 & 3,16 & 3,07 & 3,31 & 14,64 \\
\hline & 253ppm & 3,28 & 3,21 & 3,52 & 3,34 & 2,87 & 3,24 & 11,18 \\
\hline & média & 3,23 & 3,40 & 3,54 & 3,25 & 2,97 & 3,28 & \\
\hline & CV (\%) & 9,11 & 13,94 & 5,83 & 9,98 & 20,09 & & \\
\hline
\end{tabular}

*Equação linear significativa; **Equação quadrática significativa $(\mathrm{P}<0,05)$.

${ }^{1}$ Interação nível de zinco quelato e nível de lisina digestível $(\mathrm{P}<0,05)$.

Letras diferentes na mesma coluna diferem entre si para Teste $\mathrm{F}(\mathrm{P}<0,05)$. 
Dados referentes à composição química na carcaça dos frangos aos 42 dias de idade, estão apresentados na tabela 7. Houve interação $(P<0,05)$ do nível de lisina e zinco nas variáveis: porcentagem de água na matéria natural, extrato etéreo e proteína na matéria seca liofilizada.

Na porcentagem de água da carcaça constatou-se efeito linear ascendente para nível lisina digestível nas dietas que continham 43 ppm do zinco quelato, segundo a equação $\mathrm{Y}=$ $59,17676528+7,66789439$ X $\left(r^{2}=0,29\right)$ mas o nível de precisão obtido é considerado baixo. Pode-se destacar, entretanto, a indicação numérica crescente na variação média do teor de água, em resposta ao aumento dietético da lisina digestível, independentemente do nível de zinco. Essa variação, confirma observações destacadas anteriormente sobre a porcentagem de água no corpo vazio (Tabela 7).

Considerada a matéria seca liofilizada, o aumento da lisina digestível, nas dietas com 43 ppm de zinco, correspondeu a variações lineares na composição da carcaça. O extrato etéreo reduziu segundo a equação $Y=74,00807805-35,02075332 X\left(r^{2}=0,66\right)$ enquanto a proteína bruta aumentou $\left(Y=15,43842814+34,78407805 X, r^{2}=0,67\right)$. Este efeito confirma informações de que o aumento da água no corpo vazio coincide com acréscimo da proteína , segundo Claus e Weiler (1994) no tecido magro a fração de água corresponde a 3/4 de água, enquanto a protéica é apenas $1 \frac{1}{4}$, desta maneira o efeito do aumento na deposição protéica fica mais evidente pelo aumento de água na composição corpórea.

Sob o maior ou menor nível de zinco, numericamente, pôde-se observar que o aumento na concentração da lisina na dieta elevou a porcentagem de proteína na carcaça e diminuição do extrato etéreo. Há que destacar, todavia, que a composição química do corpo e suas frações pouco variam como valores relativos, o que não ocorre nas taxas diárias de deposição dos nutrientes, com valores absolutos (TRINDADE NETO et al., 2004).

A matéria mineral na carcaça teve variação quadrática, segundo a equação $Y=$ $63,9624363+146,1278306 X-78,4571086 X^{2}\left(r^{2}=0,74\right)$ indicando o nível 0,931\% de lisina digestível. Nível esse, correspondente aos melhores resultados de desempenho observados para peso médio final e ganho em peso médio. 
Tabela 7 - Composição química da carcaça em função do nível nutricional

\begin{tabular}{|c|c|c|c|c|c|c|c|c|}
\hline \multirow{2}{*}{$\begin{array}{l}\text { Variáveis } \\
\text { avaliadas }\end{array}$} & \multirow{2}{*}{ Zinco } & \multicolumn{6}{|c|}{ Lisina digestível (\%) } & \multirow{2}{*}{$\mathrm{CV}(\%)$} \\
\hline & & 0,841 & 0,874 & 0,995 & 1,019 & 1,028 & média & \\
\hline \multirow{4}{*}{$\begin{array}{l}\text { Peso } \\
\text { carcaça (g) }\end{array}$} & 43ppm & 2228 & 2185 & 2274 & 2154 & 2105 & 2189 & 4,09 \\
\hline & 253ppm & 2217 & 2105 & 2338 & 2268 & 2299 & 2245 & 4,88 \\
\hline & média & 2222 & 2145 & 2306 & 2211 & 2202 & 2217 & \\
\hline & $\mathrm{CV}(\%)$ & 1,60 & 3,43 & 3,70 & 4,80 & 6,36 & & \\
\hline \multicolumn{9}{|c|}{ Dados baseados matéria natural } \\
\hline \multirow{4}{*}{${ }^{1}$ Água (\%) } & 43ppm* & $66,79^{a}$ & $64,37^{b}$ & $67,13^{\mathrm{a}}$ & $67,53^{\mathrm{a}}$ & $66,54^{\mathrm{a}}$ & 66,47 & 1,92 \\
\hline & 253ppm & $65,39^{\mathrm{a}}$ & $66,81^{\mathrm{a}}$ & $66,03^{\mathrm{a}}$ & $66,00^{\mathrm{b}}$ & $67,27^{\mathrm{a}}$ & 66,30 & 1,70 \\
\hline & média & 66,09 & 65,59 & 66,58 & 66,77 & 66,91 & 66,39 & \\
\hline & CV (\%) & 1,85 & 2,45 & 1,08 & 1,61 & 1,50 & & \\
\hline \multirow{4}{*}{$\begin{array}{l}\text { Extrato } \\
\text { etéreo (\%) }\end{array}$} & 43ppm & 14,22 & 16,33 & 12,50 & 11,84 & 13,47 & 13,68 & 12,89 \\
\hline & 253ppm & 15,36 & 13,15 & 14,28 & 14,73 & 12,65 & 14,04 & 10,49 \\
\hline & média & 14,79 & 14,76 & 13,39 & 13,28 & 13,06 & & \\
\hline & CV (\%) & 7,21 & 15,48 & 8,55 & 12,86 & 7,44 & & \\
\hline \multirow{4}{*}{$\begin{array}{l}\text { Proteína } \\
\text { bruta (\%) }\end{array}$} & 43ppm & 15,55 & 15,34 & 16,48 & 17,15 & 16,64 & 16,23 & 6,67 \\
\hline & 253ppm & 15,67 & 16,56 & 15,87 & 15,59 & 17,03 & 16,14 & 6,07 \\
\hline & média & 15,61 & 15,95 & 16,18 & 16,37 & 16,84 & & \\
\hline & CV (\%) & 5,96 & 6,32 & 3,85 & 7,35 & 6,66 & & \\
\hline \multirow{4}{*}{$\begin{array}{l}\text { Matéria } \\
\text { mineral (\%) }\end{array}$} & 43ppm & 3,45 & 3,92 & 3,88 & 3,48 & 3,34 & 3,62 & 15,40 \\
\hline & 253ppm & 3,58 & 3,48 & 3,81 & 3,67 & 3,05 & 3,52 & 12,09 \\
\hline & média & 3,51 & 3,70 & 3,84 & 3,57 & 3,19 & & \\
\hline & CV (\%) & 9,98 & 14,99 & 6,39 & 10,04 & 21,78 & & \\
\hline \multicolumn{9}{|c|}{ Dados baseados matéria seca liofilizada } \\
\hline \multirow{4}{*}{$\begin{array}{l}{ }^{1} \text { Extrato } \\
\text { etéreo (\%) }\end{array}$} & 43ppm* & $42,77^{\mathrm{a}}$ & $45,92^{\mathrm{a}}$ & $38,02^{\mathrm{a}}$ & $36,47^{b}$ & $40,27^{\mathrm{a}}$ & 40,69 & 9,63 \\
\hline & 253ppm & $44,46^{\mathrm{a}}$ & $39,52^{\mathrm{b}}$ & $42,04^{\mathrm{a}}$ & $43,32^{\mathrm{a}}$ & $38,61^{\mathrm{a}}$ & 41,59 & 8,51 \\
\hline & média & 43,62 & 42,72 & 40,03 & 39,90 & 39,44 & 41,14 & \\
\hline & CV (\%) & 6,70 & 11,65 & 6,62 & 10,23 & 5,72 & & \\
\hline \multirow{4}{*}{$\begin{array}{l}{ }^{1} \text { Proteína } \\
\text { bruta (\%) }\end{array}$} & 43ppm* & $46,85^{\mathrm{a}}$ & $43,09^{b}$ & $50,16^{\mathrm{a}}$ & $52,81^{\mathrm{a}}$ & $49,76^{\mathrm{a}}$ & 48,53 & 8,79 \\
\hline & 253ppm & $45,22^{\mathrm{a}}$ & $49,99^{\mathrm{a}}$ & $46,73^{\mathrm{a}}$ & $45,89^{b}$ & $52,07^{\mathrm{a}}$ & 47,98 & 7,97 \\
\hline & média & 46,04 & 46,54 & 48,45 & 49,35 & 50,92 & 48,26 & \\
\hline & CV (\%) & 5,01 & 10,98 & 5,57 & 9,22 & 7,23 & & \\
\hline \multirow{4}{*}{$\begin{array}{l}* * \text { Matéria } \\
\text { mineral (\%) }\end{array}$} & 43ppm & 10,38 & 11,00 & 11,81 & 10,72 & 9,98 & 10,78 & 14,23 \\
\hline & 253ppm & 10,33 & 10,49 & 11,22 & 10,78 & 9,32 & 10,43 & 10,12 \\
\hline & média & 10,36 & 10,74 & 11,51 & 10,75 & 9,65 & 10,61 & \\
\hline & CV (\%) & 7,39 & 12,54 & 6,17 & 8,65 & 20,51 & & \\
\hline
\end{tabular}

*Equação linear significativa; **Equação quadrática significativa $(\mathrm{P}<0,05)$.

${ }^{1}$ Interação nível de zinco quelato e nível de lisina digestível $(\mathrm{P}<0,05)$.

Letras diferentes na mesma coluna diferem entre si para Teste $\mathrm{F}(\mathrm{P}<0,05)$.

Os níveis de lisina digestível não afetaram as porcentagens de extrato etéreo e proteína bruta nas vísceras e sangue (Tabela 8) na matéria liofilizada. A ausência de variação significativa confirma que a lisina não é direcionada para sangue e vísceras (LAWRENCE; 
FOWLER, 1997; TAKEARA, 2006). Nos frangos que consumiram ração com 43 ppm de zinco, o extrato etéreo foi menor e a proteína bruta maior no sangue e vísceras, comparados aos frangos alimentados com 253ppm de zinco.

O maior acúmulo de gordura, evidenciado em presença da alta concentração de zinco (253 ppm) sobretudo nas vísceras, pode ter decorrido de interferências do mineral em passos do metabolismo, visto a sua ação catalisadora em processos enzimáticos. Segundo Jonhson et al. (1988) a transferência do zinco, proveniente do plasma é cinco a seis vezes mais rápida do que em outros tecidos considerados maiores. Essa elevada concentração caracterizaria alta atividade metabólica, mas o excesso do mineral reduziria a atividade específica do tecido, aumentando as trocas (turn-over). Nesse caso, parte dos peptídeos absorvidos seriam, provavelmente, desaminados e utilizados na produção de energia, transformada na deposição lipídica observada.

Apesar de ser variações numéricas, o acúmulo de gordura pôde ser constatado através da porcentagem de extrato etéreo da carcaça e do corpo vazio (Tabela 7) na deposição de gordura total, na relação proteína bruta: extrato etéreo e na retenção de nitrogênio, variáveis que serão discutidas adiante. 
Tabela 8 - Composição química de sangue vísceras em função do nível nutricional

\begin{tabular}{|c|c|c|c|c|c|c|c|c|}
\hline \multirow{2}{*}{$\begin{array}{l}\text { Variáveis } \\
\text { avaliadas }\end{array}$} & \multirow{2}{*}{ Zinco } & \multicolumn{6}{|c|}{ Lisina digestível (\%) } & \multirow{2}{*}{ CV (\%) } \\
\hline & & 0,841 & 0,874 & 0,995 & 1,019 & 1,028 & média & \\
\hline \multirow{4}{*}{$\begin{array}{l}\text { Víscera } \\
\text { vazia (g) }\end{array}$} & 43ppm & 345,6 & 327,7 & 353,2 & 364,2 & 344,7 & 347,1 & 7,74 \\
\hline & 253ppm & 347,4 & 338,1 & 366,7 & 340,2 & 315,1 & 341,5 & 7,49 \\
\hline & média & 346,5 & 332,9 & 359,9 & 352,2 & 329,9 & 344,3 & \\
\hline & CV (\%) & 8,93 & 6,00 & 5,75 & 7,76 & 7,34 & & \\
\hline \multicolumn{9}{|c|}{ Dados na matéria natural } \\
\hline \multirow{4}{*}{ Água (\%) } & 43ppm & 71,22 & 72,08 & 75,24 & 73,77 & 74,91 & 73,44 & 3,39 \\
\hline & 253ppm & 71,96 & 71,49 & 70,30 & 72,85 & 71,39 & 71,60 & 2,47 \\
\hline & média & 71,59 & 71,79 & 72,77 & 73,31 & 73,15 & 72,52 & \\
\hline & CV (\%) & 2,08 & 3,12 & 3,86 & 2,70 & 4,23 & & \\
\hline \multirow{4}{*}{$\begin{array}{l}\text { Extrato } \\
\text { etéreo (\%) }\end{array}$} & 43ppm & 13,61 & 12,33 & 11,46 & 11,03 & 10,35 & 11,76 & 18,32 \\
\hline & 253ppm & 13,89 & 13,56 & 15,88 & 12,74 & 12,99 & 13,81 & 14,49 \\
\hline & média & 13,75 & 12,95 & 13,67 & 11,89 & 11,67 & 12,78 & \\
\hline & CV (\%) & 13,91 & 18,24 & 17,97 & 22,21 & 17,28 & & \\
\hline \multirow{4}{*}{$\begin{array}{l}\text { Proteína } \\
\text { bruta (\%) }\end{array}$} & 43ppm & 13,69 & 14,31 & 11,81 & 13,88 & 13,37 & 13,41 & 9,57 \\
\hline & 253ppm & 12,78 & 13,44 & 12,13 & 13,24 & 14,06 & 13,13 & 8,68 \\
\hline & média & 13,24 & 13,88 & 11,97 & 13,56 & 13,72 & 13,27 & \\
\hline & CV (\%) & 8,22 & 8,48 & 4,00 & 7,73 & 9,40 & & \\
\hline \multirow{4}{*}{$\begin{array}{l}\text { Matéria } \\
\text { mineral } \\
\text { (g/período) }\end{array}$} & 43ppm & 1,48 & 1,28 & 1,49 & 1,32 & 1,37 & 1,39 & 11,26 \\
\hline & 253ppm & 1,37 & 1,51 & 1,69 & 1,17 & 1,56 & 1,46 & 15,02 \\
\hline & média & 1,43 & 1,40 & 1,59 & 1,25 & 1,47 & 1,42 & \\
\hline & CV (\%) & 7,93 & 14,29 & 10,62 & 14,94 & 10,05 & & \\
\hline \multicolumn{9}{|c|}{ Dados na matéria seca liofilizada } \\
\hline \multirow{4}{*}{$\begin{array}{l}\text { Extrato } \\
\text { etéreo (\%) }\end{array}$} & 43ppm & 47,07 & 43,47 & 46,32 & 41,56 & 41,16 & $43,92^{b}$ & 11,51 \\
\hline & 253ppm & 49,46 & 47,36 & 53,44 & 46,71 & 45,33 & $48,46^{\mathrm{a}}$ & 10,46 \\
\hline & média & 48,27 & 45,42 & 49,88 & 44,14 & 43,25 & 46,19 & \\
\hline & CV (\%) & 10,55 & 12,42 & 8,08 & 16,45 & 7,33 & & \\
\hline \multirow{4}{*}{$\begin{array}{l}\text { Proteína } \\
\text { bruta (\%) }\end{array}$} & 43ppm & 47,75 & 51,87 & 47,66 & 53,39 & 53,30 & $50,79^{a}$ & 9,96 \\
\hline & 253ppm & 45,62 & 47,33 & 40,86 & 48,95 & 49,21 & $46,39^{b}$ & 10,74 \\
\hline & média & 46,69 & 49,60 & 44,26 & 51,17 & 51,26 & 48,59 & \\
\hline & CV (\%) & 10,04 & 11,50 & 8,59 & 13,49 & 5,86 & & \\
\hline \multirow{4}{*}{$\begin{array}{l}\text { Matéria } \\
\text { mineral } \\
\text { (g/período) }\end{array}$} & 43ppm & 5,18 & 4,65 & 6,02 & 5,04 & 5,53 & 5,28 & 12,97 \\
\hline & 253ppm & 4,91 & 5,31 & 5,69 & 4,34 & 5,46 & 5,14 & 12,42 \\
\hline & média & 5,05 & 4,98 & 5,86 & 4,69 & 5,50 & 5,21 & \\
\hline & CV (\%) & 8,28 & 12,63 & 7,40 & 13,82 & 9,91 & & \\
\hline
\end{tabular}

Letras diferentes na mesma coluna diferem entre si para Teste $\mathrm{F}(\mathrm{P}<0,05)$.

Dados referentes à deposição corporal dos nutrientes e a relação proteína: extrato etéreo, estão apresentados na tabela 9.

Constatou-se interação $(P<0,05)$ de nível de lisina e zinco na deposição lipídica da carcaça e do corpo vazio. A deposição lipídica foi mais pronunciada $(\mathrm{P}<0,05)$ quando os 
frangos consumiram dietas com 43 ppm de zinco, comparadas às dietas com 253 ppm. Sob o nível 43 ppm, o aumento da concentração de lisina correspondeu a redução linear $(\mathrm{P}<0,05)$ do acúmulo lipídico na carcaça e no corpo vazio, conforme equações $Y=595,5478399$ 371,2309998 X $\left(r^{2}=0,68\right)$ e $Y=663,4086798$ - 405,8965873 X $\left(r^{2}=0,76\right)$.

Na deposição protéica da carcaça e do corpo vazio, o acréscimo do nível de lisina propiciou aumento linear, segundo as equações $\mathrm{Y}=105,9581644+144,9115362 \mathrm{X}\left(\mathrm{r}^{2}=0,80\right)$ e $\mathrm{Y}=133,3811824+142,4793122 \mathrm{X}\left(\mathrm{r}^{2}=0,86\right)$ respectivamente. Esses dados sugerem que a exigência para máxima deposição seja igual ou acima de 1,028\% de lisina digestível, confirmando dados encontrados no rendimento de peito. Segundo Schutte e Pack (1995) Bartov e Plavnik (1998) e Kolling et al. (2005) a produção de carne nas linhagens modernas de frangos de corte pode ser aumentada fornecendo dieta com nível de proteína moderadamente elevado e os aminoácidos balanceados.

Na relação proteína bruta: extrato etéreo do corpo vazio ficou evidenciado o efeito da interação nível de lisina e zinco. Na dieta com 43 ppm de zinco observou-se efeito linear segundo equação $\mathrm{Y}=-0,480324713+1,771765868 \mathrm{X}\left(\mathrm{r}^{2}=0,71\right)$. Destaca-se, contudo, a melhor relação proteína bruta: extrato etéreo ocorrida sob o nível de 1,019\% de lisina. Esse efeito indica a melhor utilização da lisina para deposição protéica, confirmando a prioridade do aminoácido no acúmulo de massa muscular esquelética. Simultaneamente, reduziu-se a deposição lipídica.

Na dieta com 253 ppm a relação proteína: extrato etéreo do corpo vazio não foi influenciada pela variação do nível de lisina digestível.

A deposição de matéria mineral na carcaça e no corpo vazio, variou segundo equações $\mathrm{Y}=-1600,092477+3606,277900 \mathrm{X}-1931,067485 \mathrm{X}^{2}\left(\mathrm{r}^{2}=0,57\right)$ e $\mathrm{Y}=-1665,113322+$ $3754,148984 X-2009,945022 X^{2}\left(r^{2}=0,56\right)$ respectivamente. O aumento na concentração de lisina digestível na dieta sugere o nível ótimo estimado em 0,934\%, valor próximo ao nível (0,930\%) obtido para o melhor desempenho. 
Tabela 9 - Deposição de nutrientes na carcaça e no corpo vazio em função do nível nutricional

\begin{tabular}{|c|c|c|c|c|c|c|c|c|}
\hline \multirow{2}{*}{$\begin{array}{l}\text { Variáveis } \\
\text { avaliadas }\end{array}$} & \multirow[t]{2}{*}{ Zinco } & \multicolumn{6}{|c|}{ Lisina digestível (\%) } & \multirow[t]{2}{*}{$\mathrm{CV}(\%)$} \\
\hline & & 0,841 & 0,874 & 0,995 & 1,019 & 1,028 & média & \\
\hline \multicolumn{9}{|c|}{ Deposição carcaça } \\
\hline Água & 43ppm & 1045,2 & 963,1 & 1083,4 & 1011,0 & 958,1 & 1012,2 & 6,36 \\
\hline \multirow[t]{3}{*}{ (g/período) } & 253ppm & 1007,0 & 963,3 & 1100,7 & 1054,6 & 1103,8 & 1045,9 & 7,68 \\
\hline & média & 1026,1 & 963,2 & 1092,1 & 1032,8 & 1030,9 & 1029,0 & \\
\hline & CV (\%) & 4,53 & 2,60 & 4,97 & 6,10 & 10,48 & & \\
\hline \multirow{4}{*}{$\begin{array}{l}{ }^{1} \text { Lipídeo } \\
\text { (g/período) }\end{array}$} & 43ppm* & $259,7^{\mathrm{a}}$ & $300,7^{\mathrm{a}}$ & $227,0^{b}$ & $197,7^{b}$ & $226,6^{\mathrm{a}}$ & 242,4 & 17,24 \\
\hline & 253ppm & $283,5^{\mathrm{a}}$ & $220,2^{b}$ & $276,1^{a}$ & $276,5^{\mathrm{a}}$ & $233,3^{\mathrm{a}}$ & 257,9 & 13,56 \\
\hline & média & 271,6 & 260,5 & 251,6 & 237,1 & 230,0 & 250,2 & \\
\hline & CV (\%) & 9,60 & 21,95 & 11,35 & 19,00 & 9,83 & & \\
\hline \multirow{4}{*}{$\begin{array}{l}\text { *Proteína bruta } \\
\text { (g/período) }\end{array}$} & 43ppm & 231,4 & 220,1 & 259,8 & 254,7 & 234,9 & 240,2 & 10,48 \\
\hline & 253ppm & 231,8 & 233,3 & 256,5 & 239,0 & 276,8 & 247,5 & 11,62 \\
\hline & média & 231,6 & 226,7 & 258,1 & 246,8 & 255,9 & 243,8 & \\
\hline & CV (\%) & 6,61 & 6,90 & 9,16 & 12,16 & 13,93 & & \\
\hline \multirow{4}{*}{$\begin{array}{l}\text { **Matéria } \\
\text { mineral } \\
\text { (g/período) }\end{array}$} & 43ppm & 68,9 & 78,1 & 80,4 & 67,1 & 62,3 & 71,4 & 18,29 \\
\hline & 253ppm & 71,4 & 65,4 & 81,2 & 75,2 & 62,0 & 71,0 & 13,20 \\
\hline & média & 70,2 & 71,8 & 80,8 & 71,1 & 62,2 & 71,2 & \\
\hline & CV (\%) & 9,37 & 19,88 & 6,94 & 11,54 & 20,85 & & \\
\hline \multicolumn{9}{|l|}{ Deposição total } \\
\hline \multirow{4}{*}{$\begin{array}{l}\text { *Água } \\
\text { (g/período) }\end{array}$} & 43ppm & 1195 & 1103 & 1252 & 1183 & 1120 & 1171 & 6,49 \\
\hline & 253ppm & 1160 & 1108 & 1262 & 1206 & 1232 & 1193 & 6,97 \\
\hline & média & 1177 & 1105 & 1257 & 1195 & 1176 & 1182 & \\
\hline & CV (\%) & 4,05 & 1,91 & 5,16 & 6,19 & 8,45 & & \\
\hline \multirow{4}{*}{$\begin{array}{l}\text { 12Lipídeo } \\
\text { (g/período) }\end{array}$} & 43ppm* & $300,8^{a}$ & $335,0^{\mathrm{a}}$ & $261,9^{b}$ & $231,8^{b}$ & $256,6^{\mathrm{a}}$ & $277,2^{b}$ & 16,13 \\
\hline & 253ppm & $326,4^{\mathrm{a}}$ & $260,9^{b}$ & $328,8^{a}$ & $314,3^{\mathrm{a}}$ & $268,9^{\mathrm{a}}$ & $299,9^{\mathrm{a}}$ & 8,99 \\
\hline & média & 313,6 & 298,0 & 295,4 & 273,1 & 262,8 & 288,6 & \\
\hline & CV (\%) & 7,64 & 6,47 & 9,17 & 12,35 & 11,51 & & \\
\hline \multirow{4}{*}{$\begin{array}{l}\text { *Proteína bruta } \\
\text { (g/período) }\end{array}$} & 43ppm & 258,4 & 246,5 & 281,0 & 284,7 & 260,3 & 266,2 & 9,97 \\
\hline & 253ppm & 255,6 & 258,2 & 280,4 & 263,5 & 300,7 & 271,7 & 10,66 \\
\hline & média & 257,0 & 252,3 & 280,7 & 274,1 & 280,5 & 268,9 & \\
\hline & CV (\%) & 7,65 & 6,47 & 9,17 & 12,35 & 11,51 & & \\
\hline \multirow{4}{*}{$\begin{array}{l}\text { **Matéria } \\
\text { mineral } \\
\text { (g/período) }\end{array}$} & 43ppm & 72,9 & 81,2 & 84,5 & 70,8 & 65,9 & 75,1 & 17,08 \\
\hline & 253ppm & 75,1 & 69,4 & 86,3 & 78,0 & 65,8 & 74,9 & 13,09 \\
\hline & média & 74,0 & 75,3 & 85,4 & 74,4 & 65,9 & 75,0 & \\
\hline & CV (\%) & 9,28 & 18,41 & 6,43 & 10,68 & 19,54 & & \\
\hline \multicolumn{9}{|l|}{ Relação } \\
\hline \multirow{4}{*}{$\begin{array}{l}{ }^{1} \text { Proteína } \\
\text { bruta/Extrato } \\
\text { etéreo }\end{array}$} & 43ppm* & $1,09^{\mathrm{a}}$ & $0,96^{\mathrm{b}}$ & $1,29^{\mathrm{a}}$ & $1,44^{\mathrm{a}}$ & $1,25^{\mathrm{a}}$ & 1,21 & 17,43 \\
\hline & 253ppm & $1,01^{\mathrm{a}}$ & $1,26^{\mathrm{a}}$ & $1,06^{\mathrm{a}}$ & $1,06^{\mathrm{b}}$ & $1,33^{\mathrm{a}}$ & 1,14 & 17,49 \\
\hline & média & 1,05 & 1,11 & 1,18 & 1,25 & 1,29 & 1,18 & \\
\hline & CV (\%) & 11,19 & 24,09 & 12,63 & 20,42 & 11,76 & & \\
\hline
\end{tabular}

*Equação linear significativa; **Equação quadrática significativa $(\mathrm{P}<0,05)$.

${ }^{1}$ Interação nível de zinco quelato e nível de lisina digestível $(\mathrm{P}<0,05)$.

Letras diferentes na mesma coluna diferem entre si para Teste $\mathrm{F}(\mathrm{P}<0,05)$. 


\subsection{BALANÇO DE NITROGÊNIO}

Dados referentes ao consumo e à estimativa de nitrogênio ingerido e retido do ensaio II estão apresentados na Tabela 10.

Houve interação nível de lisina digestível e zinco quelato nas variáveis: matéria seca ingerida e nitrogênio ingerido.

Dados de consumo podem não coincidir com o ensaio I, devido ao período experimental, idade das aves e às condições ambientais diferenciadas.

O aumento da concentração de lisina na dieta com 43 ppm zinco, favoreceu o consumo de matéria seca até o nível 0,998\% de lisina digestível (1,137\% lisina total) conforme destaca a figura 3. Níveis acima prejudicaram o consumo de matéria seca. Esse efeito confirma, a observação de Sklan e Noy (2004) que o excesso de lisina na dieta afeta negativamente a ingestão.

O teor de lisina nas dietas com 253 ppm de zinco quelato seguiu a equação apresentada na figura 3. A ingestão foi diminuída pelo aumento de lisina digestível até o nível de $1,010 \%$ e a partir deste nível ocorreu resposta favorável ao aumento de lisina digestível na dieta. Nesse nível de zinco, os frangos responderam positivamente as maiores concentrações de lisina digestível, sem prejuízos ao consumo.

A diferença entre os níveis de zinco no consumo de matéria seca, no entanto não correspondeu a melhorias no nitrogênio retido. A ingestão de matéria seca por si só não foi indicativa da melhor suplementação de zinco quelato, pois as médias para cada nível não diferiram $(\mathrm{P}>0,05)$. A melhor variável para avaliar o balanço de nitrogênio é a fração retida desse elemento.

A digestibilidade da matéria seca não foi alterada pelos tratamentos, evidenciando-se que nos níveis empregados, tanto o zinco quelato quanto a lisina digestível, não afetaram a variável.

O aumento linear da ingestão de nitrogênio, ao elevar a concentração de lisina nas dietas com 43 ppm de zinco é esperado, quando o acréscimo de aminoácido não interfere no consumo de ração. Nesse caso, obedeceu a equação $Y=5,052737728+2,886800885 X$ $\left(r^{2}=0,74\right)$.

Na dieta com 253 ppm houve efeito quadrático em resposta ao aumento do nível de lisina, segundo equação $Y=28,54411209-34,33414246 X+17,90843065 X^{2}\left(r^{2}=0,72\right)$. O nível estimado da lisina digestível para menor ingestão de nitrogênio nas dietas com maior 
quantidade de zinco foi 0,959\%. O aumento numérico desta variável decorreu da maior concentração de aminoácidos na dieta, portanto não deve ser considerado como efeito do aminoácido.

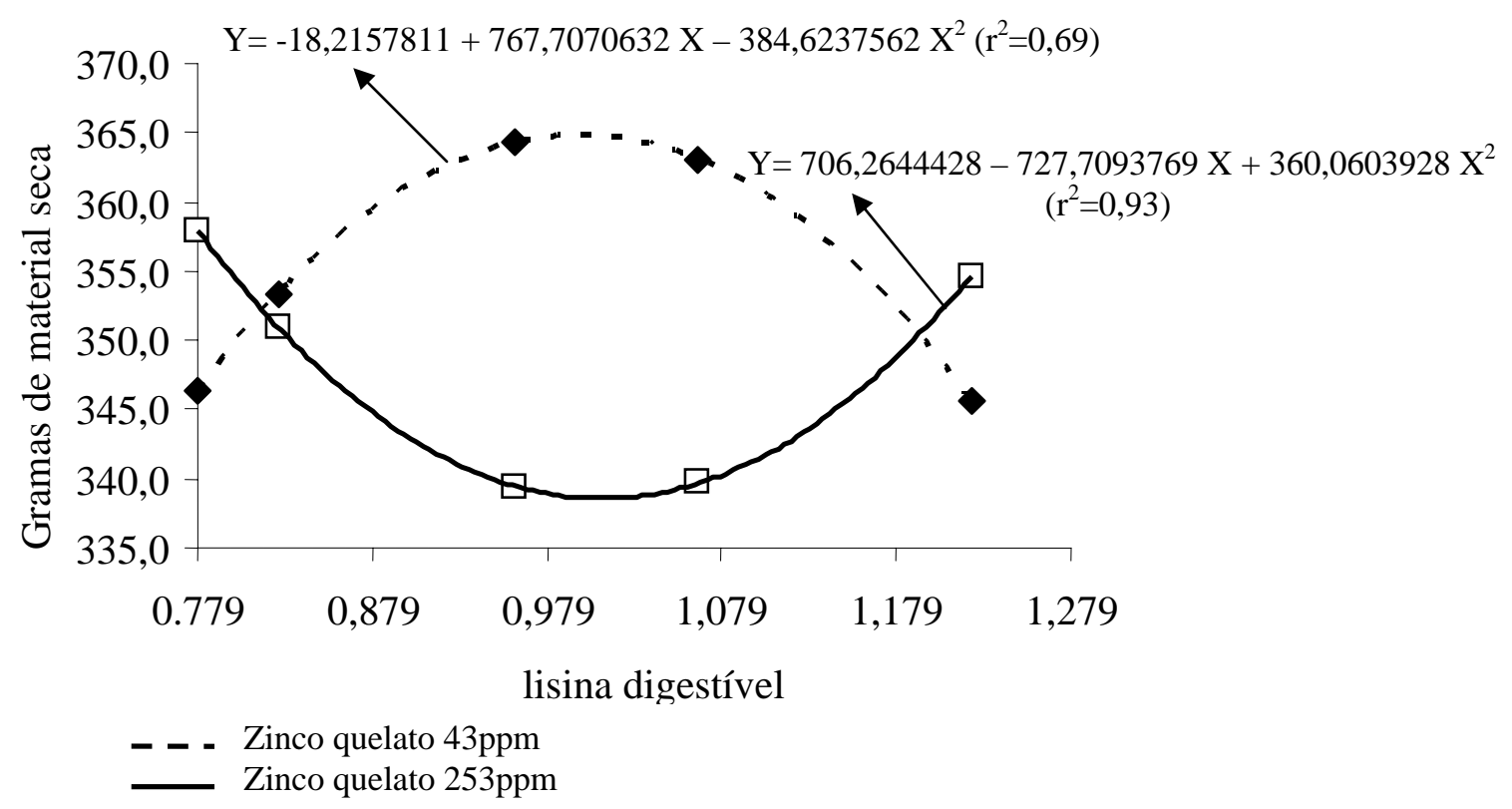

Figura 3 - Consumo de matéria seca em função dos níveis de zinco quelato e lisina digestível na dieta

O nitrogênio retido, expresso em valor absoluto, teve aumento linear com a variação crescente de lisina digestível na dieta, segundo a equação $\mathrm{Y}=5,052737728+2,886800885 \mathrm{X}$ $\left(r^{2}=0,74\right)$. Os valores observados independem do nível de zinco.

Já, o nitrogênio retido, expresso em valor relativo, não teve efeito dos níveis crescentes de lisina. O aumento na concentração do aminoácido não interferiu na retenção nitrogênio, pois o valor absoluto decorreu apenas da quantidade de nitrogênio ingerida. Do nitrogênio ingerido, cerca de $45 \%$ foi retido. Esse valor confirma a observação feita por Cauwenberghe e Burnham (2001) de que 55\% do nitrogênio ingerido é excretado pelo frango. Como se observou na matéria seca ingerida, a retenção média do nitrogênio, sob ambos níveis de zinco não diferiu $(\mathrm{P}>0,05)$ caracterizando-se ausência de efeito dos tratamentos. 
Tabela 10 - Digestibilidade das dietas em função do nível nutricional

\begin{tabular}{|c|c|c|c|c|c|c|c|c|}
\hline \multirow{2}{*}{$\begin{array}{l}\text { Variáveis } \\
\text { avaliadas }\end{array}$} & \multirow{2}{*}{ Zinco } & \multicolumn{6}{|c|}{ Lisina digestível (\%) } & \multirow{2}{*}{$\mathrm{CV}(\%)$} \\
\hline & & 0,779 & 0,825 & 0,961 & 1,066 & 1,222 & média & \\
\hline \multirow{4}{*}{$\begin{array}{l}{ }^{1} \text { Matéria } \\
\text { seca } \\
\text { ingerida (g) }\end{array}$} & 43ppm** & $339,7^{b}$ & $362,9^{a}$ & $362,0^{\mathrm{a}}$ & $361,6^{\mathrm{a}}$ & $346,5^{a}$ & 354,6 & 4,95 \\
\hline & 253ppm** & $359,5^{\mathrm{a}}$ & $349,5^{\mathrm{a}}$ & $337,1^{b}$ & $342,8^{b}$ & $353,8^{\mathrm{a}}$ & 348,5 & 4,49 \\
\hline & média & 349,6 & 356,2 & 349,6 & 352,2 & 350,1 & 351,5 & \\
\hline & CV (\%) & 6,25 & 4,38 & 5,31 & 4,27 & 3,84 & & \\
\hline \multirow{4}{*}{$\begin{array}{l}\text { Matéria seca } \\
\text { digestível } \\
(\%)\end{array}$} & 43ppm & 76,34 & 75,65 & 75,21 & 74,87 & 74,81 & 75,38 & 2,32 \\
\hline & 253ppm & 75,12 & 75,72 & 74,77 & 78,01 & 75,56 & 75,84 & 3,61 \\
\hline & média & 75,73 & 75,69 & 74,99 & 76,44 & 75,19 & 75,61 & \\
\hline & $\mathrm{CV}(\%)$ & 3,30 & 3,62 & 1,88 & 4,10 & 1,51 & & \\
\hline \multirow{4}{*}{$\begin{array}{l}{ }^{1} \text { Nitrogênio } \\
\text { ingerido (g) }\end{array}$} & 43ppm* & $12,18^{\mathrm{b}}$ & $12,47^{\mathrm{a}}$ & $13,34^{\mathrm{a}}$ & $12,76^{\mathrm{a}}$ & $13,08^{\mathrm{a}}$ & 12,77 & 5,26 \\
\hline & 253ppm** & $12,89^{\mathrm{a}}$ & $12,01^{\mathrm{a}}$ & $12,42^{\mathrm{b}}$ & $12,10^{\mathrm{b}}$ & $13,36^{\mathrm{a}}$ & 12,56 & 5,63 \\
\hline & média & 12,54 & 12,24 & 12,88 & 12,43 & 13,22 & 12,66 & \\
\hline & CV (\%) & 6,25 & 4,37 & 5,31 & 4,27 & 3,85 & & \\
\hline \multirow{4}{*}{$\begin{array}{l}\text { *Nitrogênio } \\
\text { retido (g) }\end{array}$} & 43ppm & 7,22 & 7,27 & 8,65 & 7,96 & 8,42 & 7,90 & 10,76 \\
\hline & 253ppm & 7,58 & 6,87 & 7,91 & 8,03 & 8,60 & 7,80 & 11,22 \\
\hline & média & 7,40 & 7,07 & 8,28 & 8,00 & 8,51 & 7,85 & \\
\hline & CV (\%) & 11,18 & 8,35 & 7,34 & 10,06 & 6,41 & & \\
\hline \multirow{4}{*}{$\begin{array}{l}\text { Nitrogênio } \\
\text { retido (\%) }\end{array}$} & 43ppm & 42,38 & 45,85 & 43,50 & 46,13 & 44,28 & 44,43 & 8,29 \\
\hline & 253ppm & 45,75 & 44,16 & 43,25 & 42,35 & 44,80 & 44,06 & 5,85 \\
\hline & média & 44,07 & 45,01 & 43,38 & 44,24 & 44,54 & 44,25 & \\
\hline & CV (\%) & 7,31 & 5,58 & 11,62 & 5,92 & 3,81 & & \\
\hline
\end{tabular}

*Equação linear significativa; **Equação quadrática significativa $(\mathrm{P}<0,05)$.

${ }^{1}$ Interação nível de zinco quelato e nível de lisina digestível $(\mathrm{P}<0,05)$.

Letras diferentes na mesma coluna diferem entre si para Teste $\mathrm{F}(\mathrm{P}<0,05)$.

Dados referentes aos valores de energia e sua utilização estão na tabela 12.

Houve interação nível de lisina e zinco nas variáveis energia bruta ingerida, energia excretada e balanço energético.

Sob o nível 43 ppm de zinco, a variação na ingestão de energia ocorreu segundo a equação $Y=-251,615033+3889,378998 X-1960,541017 X^{2}\left(r^{2}=0,66\right)$. Na concentração 253 ppm do mineral quelato a equação correspondente foi $Y=3067,172006$ - 2963,478122 X $+1452,82129 X^{2}\left(r^{2}=0,99\right)$. Estas respostas ratificam as observações feitas sobre a ingestão de matéria seca (Tabela 10). Na dieta com 43 ppm de zinco a maior ingestão ocorreu no nível estimado de 0,992\% de lisina digestível e na dieta com 253 ppm a menor ingestão se deu no nível estimado de 1,020\% de lisina digestível. 
Na dieta com 43ppm de zinco quelato as variações na energia bruta excretada e no balanço energético, devido ao aumento de lisina digestível, tiveram efeito quadrático, segundo as respectivas equações $\mathrm{Y}=-95,9045421+413,3026622 \mathrm{X}-197,6693189 \mathrm{X}^{2}\left(\mathrm{r}^{2}=0,72\right)$ e $\mathrm{Y}=$ $477,584306+1914,503289 X-975,092262 X^{2}\left(r^{2}=0,64\right)$. Os níveis estimados equivalentes foram $1,045 \%$ e $0,982 \%$ de lisina digestível. Este efeito condiz com a variação na ingestão de matéria seca.

Na dieta com 253ppm de zinco quelato o aumento de lisina digestível na dieta não influenciou a energia bruta excretada e o balanço energético, mesmo que o consumo de matéria seca tenha sido afetado pelo nível de lisina (Tabela 10). Este efeito confirma as observações anteriores que o excesso provável de nutrientes no nível maior de zinco tenha sido direcionado para deposição lipídica.

A energia metabolizável e a relação energia metabolizável: energia bruta não foram alteradas com a variação dos níveis de zinco e lisina digestível. As variações ocorridas na relação energia metabolizável: energia bruta, independentemente do nível de zinco, tiveram o melhor valor no nível $0,961 \%$ de lisina digestível. Valor esse, próximo ao melhor nível estimado (0,93\%) no ensaio de desempenho. 
Tabela 11 - Valores de energia das dietas em função do nível nutricional

\begin{tabular}{|c|c|c|c|c|c|c|c|c|}
\hline \multirow{2}{*}{$\begin{array}{l}\text { Variáveis } \\
\text { avaliadas }\end{array}$} & \multirow{2}{*}{ Zinco } & \multicolumn{6}{|c|}{ Lisina digestível (\%) } & \multirow{2}{*}{ CV $(\%)$} \\
\hline & & 0,779 & 0,825 & 0,961 & 1,066 & 1,222 & média & \\
\hline \multirow{4}{*}{$\begin{array}{l}{ }^{1} \text { Energia bruta } \\
\text { ingerida (kcal) }\end{array}$} & 43ppm* & $1551,5^{b}$ & $1672,0^{\mathrm{a}}$ & $1675,0^{\mathrm{a}}$ & $1647,0^{\mathrm{a}}$ & $1581,3^{\mathrm{a}}$ & 1625,4 & 5,18 \\
\hline & 253ppm* & $1641,3^{\mathrm{a}}$ & $1610,2^{\mathrm{a}}$ & $1559,3^{b}$ & $1261,2^{b}$ & $1614,7^{\mathrm{a}}$ & 1537,3 & 4,35 \\
\hline & média & 1596,4 & 1641,1 & 1617,2 & 1454,1 & 1598,0 & 1581,4 & \\
\hline & CV (\%) & 6,25 & 4,39 & 5,32 & 4,27 & 3,85 & & \\
\hline \multirow{4}{*}{$\begin{array}{l}{ }^{1} \text { Energia bruta } \\
\text { excretada } \\
\text { (kcal) }\end{array}$} & 43ppm* & $102,1^{b}$ & $116,2^{\mathrm{a}}$ & $117,9^{\mathrm{a}}$ & $118,6^{\mathrm{a}}$ & $114,7^{\mathrm{a}}$ & 113,9 & 9,32 \\
\hline & 253ppm & $117,2^{\mathrm{a}}$ & $111,2^{\mathrm{a}}$ & $114,6^{\mathrm{a}}$ & $98,5^{\mathrm{b}}$ & $113,1^{\mathrm{a}}$ & 110,9 & 14,08 \\
\hline & média & 109,6 & 113,7 & 116,2 & 108,6 & 113,9 & 112,4 & \\
\hline & CV (\%) & 14,84 & 13,27 & 7,48 & 15,73 & 6,00 & & \\
\hline \multirow{4}{*}{$\begin{array}{l}\text { Energia } \\
\text { metabolizável } \\
\text { (kcal) }\end{array}$} & 43ppm & 3662,7 & 3646,3 & 3647,3 & 3569,8 & 3571,3 & 3619,5 & 2,40 \\
\hline & 253ppm & 3590,7 & 3653,3 & 3607,3 & 3692,2 & 3605,2 & 3629,7 & 3,26 \\
\hline & média & 3626,7 & 3649,8 & 3627,3 & 3631,0 & 3588,3 & 3624,6 & \\
\hline & CV (\%) & 3,27 & 3,26 & 1,97 & 3,75 & 1,5 & & \\
\hline \multirow{4}{*}{$\begin{array}{l}\text { Relação } \\
\text { energia } \\
\text { metabolizável/ } \\
\text { energia bruta } \\
(\%) \\
\end{array}$} & 43ppm & 80,20 & 79,15 & 78,84 & 78,37 & 78,24 & 78,96 & 2,30 \\
\hline & 253ppm & 78,62 & 79,3 & 77,97 & 81,06 & 78,98 & 79,19 & 3,36 \\
\hline & média & 79,41 & 79,23 & 78,41 & 79,72 & 78,61 & 79,07 & \\
\hline & CV (\%) & 3,27 & 3,26 & 1,97 & 3,75 & 1,5 & & \\
\hline \multirow{4}{*}{$\begin{array}{l}{ }^{1} \text { Balanço } \\
\text { energético } \\
\text { (kcal) }\end{array}$} & 43ppm* & $415,08^{\mathrm{a}}$ & $441,14^{\mathrm{a}}$ & $440,37^{\mathrm{a}}$ & $430,40^{\mathrm{a}}$ & $412,48^{\mathrm{a}}$ & 427,89 & 6,02 \\
\hline & 253ppm & $430,00^{a}$ & $425,53^{a}$ & $405,27^{\mathrm{b}}$ & $421,91^{\mathrm{a}}$ & $425,20^{\mathrm{a}}$ & 421,58 & 5,05 \\
\hline & média & 422,54 & 433,34 & 422,82 & 426,16 & 418,84 & 424,74 & \\
\hline & CV (\%) & 6,77 & 5,23 & 6,31 & 5,13 & 4,43 & & \\
\hline
\end{tabular}

*Equação quadrática significativa $(\mathrm{P}<0,05)$.

${ }^{1}$ Interação nível de zinco quelato e nível de lisina digestível $(\mathrm{P}<0,05)$.

Letras diferentes na mesma coluna diferem entre si para Teste $\mathrm{F}(\mathrm{P}<0,05)$. 


\section{CONCLUSÕES}

Nas condições presentes, a suplementação da dieta com zinco quelato afetou as exigências de lisina digestível.

De acordo com o desempenho, o nível de 0,93\% de lisina digestível ou 1,06\% de lisina total supre as necessidades de frango de corte dos 22 aos 42 dias de idade, ao receberem dietas com 43 ppm de zinco quelato.

Ao consumirem dietas com 253 ppm de zinco quelato recomenda-se nível igual ou acima de $1,028 \%$ de lisina digestível, para frangos de corte na mesma idade. A maior inclusão do zinco, porém não confere benefício adicionais na criação

Considerando deposição protéica e rendimento de cortes, o nível de lisina digestível recomendável deve ser no mínimo 1,028\%, independentemente da suplementação de zinco quelato na dieta. 


\section{CONSIDERAÇÕES}

Visto a interação do nível de zinco e nível de lisina na dieta, propõe-se que a exigência de lisina digestível seja variável com nível de zinco na dieta.

Sugerem-se novos estudos, para elucidar o papel do zinco no metabolismo, principalmente no trato gastrointestinal.

A demanda de lisina para síntese protéica parece ser maior que a exigência aferida como desempenho in vivo.

Torna-se plausível a comparação do zinco quelato com o zinco na forma de óxido. Na forma óxido, não obstante, devem ser adicionados demais nutrientes que compõem o quelato, uma vez que o zinco representa apenas $7 \%$ do composto. Os demais componentes do quelato devem ser considerados no ajuste nutricional final, para que numa nova comparação não se caracterizem efeitos aditivos em favor de certos tratamentos. 


\section{REFERÊNCIAS}

ACAR, N.; MORAN JR., E.T.; BILGILI, S.F. Live performance and carcass yield of male broilers from two commercial strain crosses receiving rations containing lysine below and above the established requirement between six and eight weeks of age. Poultry Science, v.70, n.12, p.2315-2321. 1991.

AGROCRES Manual de manejo de frangos agRoss 2004 Disponível em: $<$ http://www.agroceresross.com.br/servlet/navSrvt?cmd=listPublicacaoFrango\&id=47>. Acesso em: 2 Jun 2006.

ALBITECH NUTRICIONALS. Suplementos: Multiminerais quelatos. Disponível em: <www.albitech.com.br>. Acesso em: 07 jun.2006.

AOAC (Association on Official Analytical Chemists). Official Methods of Analysis, $14^{\text {th }}$ ed. Arlington, VA.: Association of Official Analytical Chemists 1984. 1141p.

AOYAGI, S.\& BAKER, D. H. Nutritional evaluation of copper-lysine and zinc-lysine complexes for chicks. Poultry Sci., v.72, p.165-171. 1993.

ARAÚJO, C. S. S.;ARTONI, S. M. B.;ARAÚJO, L. F.;JUNQUEIRA, O. M.;BORGES, S. A. Desempenho, Rendimento de Carcaça e Excreção de Cálcio de Frangos de Corte Alimentados com Diferentes Níveis de Aminoácidos e Cálcio no Período de 22 a 42 Dias de Idade. R.

Bras. Zootec., v.31, n.6, p.2209-2215.

ARAÚJO, L. F.; JUNQUEIRA, O. M.; ARAÚJO, C. S. S.; ARTONI, S. M. B.; FARIA FILHO de.Diferentes critérios de formulação de rações para frangos de corte no período de 1 a 21 dias de idade. Revista Brasileira de Ciência Avícola -Set - Dez 2002 / v.4 / n.3/ 195 202

BAKER, D. H.; PARSONS, C. M.; FERNANDEZ, S. Digestible amino acid requirements of broiler chickens based upon ideal protein considerations. In: ARKANSAS NUTRITION CONFERENCE, 1993, Fayetteville. Proceedings... Fayetteville: University of Arkansas, 1993. p.22-32

BAKER, D. H. Ideal amino acids patterns for broiler chicks. In: Amino acids in animal nutrition, 2ed. Edinburgh: CABI Publishing, p.223-235, 2003.

BARBOZA, W.A. Exigências nutricionais de lisina para duas marcas comerciais de frangos de corte. Viçosa, MG: Universidade Federal de Viçosa, 1998. 116p. Tese (Doutorado em Zootecnia) - Universidade Federal de Viçosa, 1998. 
BARBOZA, W. A.;ROSTAGNO, H. S.;ALBINO, L. F. T.;RODRIGUES, P. B. Níveis de Lisina para Frangos de Corte de 22 a 40 e 42 a 48 dias de Idade. R. Bras. Zootec., v.29, n.4, p.1091-1097. 2000.

BARTLETT, J. R.;SMITH, M. O. Effects of different levels of zinc on the performance and immunocompetence of broilers under heat stress. Poult Sci, v.82, n.10, p.1580-1588. 2003.

BARTOV, I. Interrelationship between the effects of dietary factors and feed withdrawal on the content and composition of liver fat in broiler chicks. Poult Sci, v.75, p.632-641. 1996.

BARTOV, I.; PLAVNIK, I. Moderate excess of dietary protein increases breast meat yield of broilers chicks. Poult Sci, v.77, p.680-688.1998, 1998.

BELLAVER, C. e VIOLA, E. S. Qualidade de carcaça, nutrição e manejo nutricional. In: CONGRESSO BRASILEIRO DE VETERINÁRIOS ESPECIALISTAS EM SUÍNOS, 8, 1997, Foz do Iguaçu. Anais... p.152-157.

BELLAVER, C. O uso de microingredientes (aditivos) na formulação de dietas para suínos e suas implicações na produção e na segurança alimentar. In: CONGRESSO MERCOSUR DE PRODUCCIÓN PORCINA, 2000, Buenos Aires, p.56-78.

BELLAVER, C.; GUIDONI, A. L.; BRUM, P.A.R.; ROSA, P.S. Estimativas das exigências de lisina e de energia metabolizável em frangos de corte de 1 a 21 dias de idade, utilizando-se uma variável multivariada canônica. Revista Brasileira de Zootecnia, v.31, n.1, p.71-78, 2002.

BERCOVICI D, SUIDA D. Nutrição protéica de frangos de corte . In: SIMPÓSIO SOBRE NUTRIÇÃO E TECNOLOGIA DE PRODUÇÃO DE RAÇÕES; 1998; Campinas, SP. Brasil. Anais... p. 42-54, 1998

BORGES, A.F.; OLIVEIRA, R.F.M.; DONZELE, J.L. Exigência de lisina para pintos de corte machos mantidos em ambiente com alta temperatura. Revista Brasileira de Zootecnia, v.31, n.1, p.394-401, 2002a. (Suplemento)

BORGES, A. F.;OLIVEIRA, R. F. M.;DONZELE, J. L.;ORLANDO, U. A. D.;FERREIRA, R. A.;SARAIVA, E. P. Exigência de Lisina para Frangos de Corte Machos no Período de 22 a 42 Dias de Idade, Mantidos em Ambiente Quente $\left(26^{\circ} \mathrm{C}\right)$. Revista Brasileira de Zootecnia, v.31, n.5, p.1993-2001. 2002b.

BRANDÃO-NETO, J.;STEFAN, V.;MENDONCA, B. B.;BLOISE, W.;CASTRO, A. V. B. The essential role of zinc in growth. Nutrition Research, v.15, n.3, p.335. 1995.

BURRELL, A. L.;DOZIER, W. A.;DAVIS, A. J.;COMPTON, M. M.;FREEMAN, M. E.;VENDRELL, P. F.;WARD, T. L. Responses of broilers to dietary zinc concentrations and 
sources in relation to environmental implications. British Poultry Science, v.45, n.2, p.225. 2004.

CAUWENBERGHE, S. V.;BURNHAM, D. New developments in amino acid and protein nutrition of poultry, as related to optimal performance and reduced nitrogen excretion. In:13th Eur. Symp. Poult. Nutr. Anais... Blankenberge, Belgium, 2001. 141-149 p.

CELLA, P. S.;DONZELE, J. L.;OLIVEIRA, R. F. M.;ALBINO, L. F. T.;FERREIRA, A. S.;GOMES, P. C.;VALERIO, S. R. Níveis de Lisina Mantendo a Relação Aminoacídica para Frangos de Corte no Período de 1 a 21 Dias de Idade, em Diferentes Ambientes Térmicos. Revista Brasileira de Zootecnia, v.30, n.2, p.433-439. 2001.

CHENG, J.;KORNEGAY, E. T.;SCHELL, T. Influence of dietary lysine on the utilization of zinc from zinc sulfate and a zinc-lysine complex by young pigs. J. Anim Sci., v.76, n.4, p.1064-1074. 1998.

CHUNG, T. K. \& BAKER, D. H. Ideal aminoacid pattern for 10 kilogram pigs. J. Anim. Sci., v. 70, n.10, p.3102-3111, 1992.

CLAUS, R.; WEILER, U. Endocrine regulation of growth and metabolism in the pig: a review. Livestock Production Science, v.37, n.3, p. 245-260, 1994.

COIC, Y. \& COPPENET, M. Les oligo-elements en agriculture et elevage. Paris.Inra Editions. 1989. 114p.

CONHALATO, G.S.; DONZELE, J.L.; ALBINO, L.F.T. Níveis de lisina digestível para frangos de corte machos na fase de 21 a 42 dias de idade. Revista Brasileira de Zootecnia, v.28, n.1, p.91-97, 1999.

COSSACK, Z. T. Somatomedin-C and zinc status in rats as affected by Zn, protein and food intake. Br J Nutr, v.56, p.163-169. 1986.

COSTA, F.G.P.; ROSTAGNO, H.S.; ALBINO, L.F.T. Níveis dietéticos de lisina para frangos de corte de 1 a 21 e 22 a 40 dias de idade. Revista Brasileira de Zootecnia, v.30, n.5, p.1490-1497, 2001.

COUSINS, R. J. Absortion, transport, and hepatic metabolidm of cooper and zinc: special reference to metallothionein and ceruloplasmi. Phy. Rev., v.65, p.238-309. 1985.

D’MELLO, J. P. F. Responses of growing poultry to amino acids. In: AMINO acids in animal nutrition, 2ed. Edinburgh: CABI Publishing, p.237-263, 2003. 
DESCHEPPER, K.; DE GROTTE, G. Effect of dietary protein essential and non-essential amino acids on the performance of male broiler chickens. British Poultry Science, v.36, p.229-245, 1995.

EMMERT, J. L.;BAKER, D. H. Zinc stores in chickens delay the onset of zinc deficiency symptoms. Poultry Science, v.74, p.1011-1021. 1995.

EITS, R. M.;KWAKKEL, R. P.;VERSTEGEN, M. W. A.;EMMANS, G. C. Responses of broiler chickens to dietary protein: effects of early life protein nutrition on later responses. British Poultry Science, v.44, n.3, p.398. 2003.

FATUFE, A. A.;TIMMLER, R.;RODEHUTSCORD, M. Response to lysine intake in composition of body weight gain and efficiency of lysine utilization of growing male chickens from two genotypes. Poult Sci, v.83, n.8, p.1314-1324. 2004.

FERNANDES, E. A. Pontos críticos na nutrição e manejo de frangos de corte. In: SIMPÓSIO SOBRE MANEJO E NUTRIÇÃO DE AVES E SUÍNOS E TECNOLOGIA DA PRODUÇÃO DE RAÇÃO, 2001, Campinas. Anais... Campinas: Colégio Brasileiro de Nutrição Animal, CBNA, 2001. 406p.

FRAKER, P.J.; KING, L.E.; LAAKKO, T.; VOLLMER, T.L. The dynamic link between the integrity of the immune system and zinc status. J. Nutr. 130: 1399S-1406S; 2000.

FRIESEN, K. G.; NELSSEN, J. L.; GOODBAND, R. D. The use of compositional growth curves for assessing the response to dietary lysine by high-lean growth gilts. Anim. Sci, v.62, n.1, p.159-169, 1996.

FULLER, M., WANG, T.C. Digestible ideal protein - a measure of dietary protein value. Pig News Information, v.11, n.3, p.353-357, 1990.

HESS, J. B.;BILGILI, S. F.;PARSON, A. M.;DOWNS, K. M. Influence of complexed zinc products on live performance and carcass grade of broilers. J. Appl. Anim. Res., v.19, p.4960. 2001.

HURWITZ, S.D.; SKLAN, H.; TALPAZ, H.; PLAVNIK, I. The effect of dietary level on the lysine and arginine requerimentes of growg chickes. Poultry Science, v.77, p.689-696, 1998.

JOHNSON, P. E.;HUNT, J. R.;RALSTON, N. V. The effect of past and current dietary Zn intake on Zn absorption and endogenous excretion in the rat. Journal of Nutrition, v.118, n.10, p.1205-1209. 1988.

JONGBLOED, A.W., LENIS, N.P. Alteration of nutrition as a means to reduce enviromental pollution by pigs. Liv. Prod. Sci., v.31, n.1/2, p.75-94, 1992. 
KIDD, M. T.;ANTHONY, N. B.;LEE, S. R. Progeny performance when dams and chicks are fed supplemental zinc. Poult Sci., v.71, p.1201-1206. 1992.

KIDD, M. T.;QURESHI, M. A.;FERKET, P. R.;THOMAS, L. M. Blood clearance of Eschericheria coli and evaluation of mononuclear-phagocytic system as influenced by supplemental dietary zinc methionine in young turkeys. Poult Sci., v.73, p.1318-1389. 1994.

KIDD, M. T.;KERR, B. J.;ANTHONY, N. B. Dietary interactions between lysine and threonine in broilers. Poult Sci, v.76, n.4, p.608-614. 1997.

KOLLING, A. V.;KESSLER, A. M.;RIBEIRO, A. M. L. Desempenho e Composição Corporal de Frangos de Corte Alimentados com Diferentes Níveis de Proteína e de Aminoácidos ou com Livre Escolha das Dietas. R. Bras. Zootec., v.34, n.1, p.98-103. 2005.

LANA, S.R.V.; OLIVEIRA, R.F.M. ;DONZELE, J.L. ;GOMES, P.C; VAZ, R.G.M.V.; REZENDE, W.O. Níveis de Lisina Digestível em Rações para Frangos de Corte de 22 a 42 Dias de Idade, Mantidos em Ambiente de Termoneutralidade R. Bras. Zootec., v.34, n.5, p.1624-1632, 2005.

LAWRENCE, T.L.J., FOWLER, V.R. Growth of farm animals. Wallingford: Cab International, 1997. 330p.

LECLERCQ, B. Les rejet azote Issus de láviculture: importance et progress envisageables. INRA Prod. Anim., v. 9, p.91-101, 1996.

LESSON, S.; CASTON, L.; SUMMERS, J.D. Broiler response to energy or energy and protein dilution in the finisher diet. Poultry Science, v.75,n.4, p.522-528. 1996a.

LEESON, S.;ZUBAIR, A. K. Nutrition of the broiler chickens around the period of compensatory growth. Poult Sci, v.76,n.7, p.992-999. 1997.

MACDONALD RS. The role of zinc in growth and cell proliferation. J Nutr.; 130(5):1500S8S, 2000.

MC LEOD, M. G. Effects of amino acid balance and energy: protein ratio on energy and nitrogen metabolism in male broiler chicken. British Poultry Science, v.38, p.405-411. 1997.

MAFRA, D.; COZZOLINO, S. M. F.. The importance of zinc in human nutrition. Rev. Nutr., Campinas, v. 17, n. 1, 2004. Available from: $<$ http://www.scielo.br/scielo.php?script=sci_arttext\&pid=S141552732004000100009\&lng=en\&nrm=iso > . Access on: 25 Oct 2006. doi: 10.1590/S141552732004000100009 . 
MCCALL, K.A.; HUANG, C.C.; FIERKE, C.A. Function and mechanism of zinc metalloenzymes. J Nutr. , v. 130(5):1437S-46, 2000.

MCDOWELL, L. R. Minerals in animal and human nutrition.: San Diego: Academic. 1992. 544 p.

MCLEOD, M. G. Effects of amino acid balance and energy: protein ratio on energy and nitrogen metabolism in male broiler chicken. British Poultry Science, v.38, p.405-411. 1997.

MITCHELL, H.F. Comparative nutrition of man and domestic animals. New York: Academic Press, 1964. p.567-647.

MOHANNA, C.;NYS, Y. Excess Zinc in manure of broiler chicks: Decrease in Zinc supplementation and use of phytase improve its retention in the carcasses. Proceedings of the 11th European Symposium on Poultry Nutrition. Faaborg, 1997. 459-461 p.

MOHANNA, C. \& NYS, Y. Effect of dietary zinc content and sources on the growth, body zinc deposition and retention, zinc excretion and immune response in chickens. British Poultry Science, v.40, n.1, p.108. 1999.

MURAMATSU, T.;TAKASU, O.;FURUSE, M.;TASAKI, I.;OKUMURA, J. Influence of the gut microflora on protein synthesis in tissues and in the whole body of chicks. Biochem. J., v.246, p.475-479. 1987.

NATIONAL RESEARCH COUNCIL - NRC. 1994. Nutrient requirements of poultry. 9.ed. 155p.

NUNES, R. V.;NASCIMENTO, A. H.;ALBINO, L. F. T.;ROSTAGNO, H. S. Resultados de Pesquisa em Nutrição de Aves no Brasil Resumo dos Últimos 5 anos. Rev. Bras. Cienc. Avic., v.2, n.2, p.115-139. 2000.

PACK, M. Proteína ideal para frangos de corte. Conceito atual. In: COFERÊNCIA APINCO DE CIÊNCIA E TECNOLOGIA AVÍCOLAS. 1995, Curitiba. Anais... Campinas:FACTA, 1995. p. $95-110$

PIMENTEL, J. L.;COOK, M. E.;GREGER, J. L. Research Note:Bioavailability of zincmethionine for chicks. Poultry Sci., v.70, p.1637-1639. 1991.

ROSTAGNO, H.S. e PACK, M. Growth and breast meat responses of different broiler strains to dietary lysine. Proceedings of the 10th European Symposium on Poultry Nutrition, Antalya, Turkey, 1995,p. 260-262.

ROSTAGNO, H.S., BARBARINO JUNIOR, P., BARBOZA, W.A. Exigências nutricionais das aves determinadas no Brasil. In: SIMPÓSIO INTERNACIONAL SOBRE EXIGÊNCIAS 
NUTRICIONAIS DE AVES E SUÍNOS, 1996, Viçosa. Anais... Viçosa: Departamento de Zootecnia, UFV, 1996. 457p.

ROSTAGNO, H. S.; SILVA, D. J.; COSTA, P. M. A.; FONSECA, J. B.; SOARES, P. R.; PEREIRA, J. A. A. e SILVA, M. A. Composição de alimentos e exigências nutricionais de aves e suínos. (Tabelas Brasileiras). Viçosa: Imp. Univ., 2000. 141p.

ROSTAGNO, H. S.; ALBINO, L.F.T.; DONZELE, J.L.; GOMES, P.C.; OLIVEIRA; R.F., LOPES; D.C.; FERREIRA, A.S.; BARRETO, S.L.T. Composição de alimentos e exigências nutricionais de aves e suínos. (Tabelas Brasileiras). Viçosa: Imp. Univ., 2005. 186p.

RUTZ, F.; LIMA, G.J.M.M. O uso de antimicrobianos como promotores de crescimento no Brasil. In: CONGRESSO DA ABRAVES, 10.,2001, Porto Alegre, Anais... p.68-77.

SAKOMURA, N.K.; SILVA, R. Conceitos aplicáveis à nutrição de não ruminantes. Cadernos Técnicos da Escola de Vetrinária da UFMG, v.22, p.125-146, 1998.

SALGUEIRO, MJ, Zinc as an essencial micronutrient: a review. Nutr Res.; 20(5): 737-55, 2000.

SCHLEGEL, P. \& W. WINDISCH. Bioavailability of zinc glycinate in comparison with zinc sulphate in the presence of dietary phytate in an animal model with 65Zn labelled rats.

Journal of Animal Physiology and Animal Nutrition, v.90, n.5-6, p.216-222. 2006.

SCOTT, M.E. \& KOSKI. K.G. Zinc deficiency impairs immune responses against parasitic nematode infections at intestinal and systemic sites. J. Nutr. 130 (5S Suppl):1412S, 2000.

SCHUTTE, J.B.; PACK, M. Sulfur amino acid requirement of broiler chicks from 14 to 38 days of age. 1. Performance and carcass yield. Poult Sci, v.74, p.480-487, 1995.

SILVA, J.H.V.;ALBINO, L.F.T.;NASCIMENTO, A.H. Estimativas da Composição Anatômica da Carcaça de Frangos de Corte com Base no Nível de Proteína da Ração e Peso da Carcaça. R. Bras. Zootec., v.32, n.2, p.344-352. 2003.

SKLAN, D.\& NOY, Y. Catabolism and deposition of amino acids in growing chicks: effect of dietary supply. Poult Sci, v.83, n.6, p.952-961. 2004.

SPEARS; J.W.; HARVEY, R.W.; BROWN JR., T.T.. Effects of zinc methionine and zinc oxide on performance, blood characteristics, and antibody titer response to viral vaccination in stressed feeder calves. J. Am. Vet. Med. Assoc., v.199, 1731-1733, 1991.

STATISTICAL ANALYSES SYSTEM - SAS. User's guide: statistics. 12.ed. New York: SCOTT, M.L. \& Associates. 2004. 1686p. 
STERLING, K. G.;PESTI, G. M.;BAKALLI, R. I. Performance of different broiler genotypes fed diets with varying levels of dietary crude protein and lysine. Poult Sci, v.85, n.6, p.10451054. 2006.

SUSENBETH, A. Factors affecting lysine utilization in growing pigs: na analysis of literature data. Liv. Prod. Sci., v.43, n.3 ,p.193-204, 1995.

SWATSON, H. K.;GOUS, R.;IJI, P. A.;ZARRINKALAM, R.;CALDARA, F. R. Effect of dietary protein level, amino acid balance and feeding level on growth, gastrointestinal tract, and mucosal structure of the small intestine in broiler chickens. Anim. Res., v.51, p.501-515. 2002.

UNDERWOOD, E. J.;SUTTLE, N. The Mineral Nutrition of Livestock. Penicuik, Edinburgh, UK: Foundation for Animal Health and Welfare. 1999. 624 p.

TAKEARA P. Lisina digestível para frangos de corte machos. Dissertação (Mestrado em Nutrição Animal) - Faculdade de Medicina Veterinária e Zootecnia , USP, 90p., 2006.

TRINDADE NETO, M. A.;PETELINCAR, I. M.;BERTO, D. A.;SCHAMMASS, E. A.;BISINOTO, K. S.;CALDARA, F. R. Níveis de Lisina para Leitões na Fase Inicial-1 do Crescimento Pós-desmame: Composição Corporal aos 11,9 e 19,0 kg. R. Bras. Zootec., v.33, n.6 (Supl. 1), p.1777-1789. 2004.

VALÉRIO, S.R.; OLIVEIRA, R.F.M.; DONZELE, J.L. Níveis de lisina digestível em rações, mantendo ou não a relação aminoacídica, para frangos de corte de 22 a 42 dias de idade, sob condições de estresse por calor. Revista Brasileira de Zootecnia, v.32, n.2, p.372-382, 2003.

VAN LUNEN, T. A. Ideal protein requirements of modern genotypes. Pigs, frebuary, p.1213, 1995.

WANG, T.C., FULLER, M. The optimum dietary amino acid pattern for growing pigs.

British J. Nut., v.62, n.1, p.77-89, 1989.

WEDEKIND, K. J.;COLLINGS, G.;HANCOCK, J.;TITGEMEYER, E. The bioavailability of zincmethionine relative to zinc sulfate is affected by calcium level. Poultry Sci., v.73 (Suppl. 1), p.114-117. 1994.

WHITTEMORE, C.T., ELSLEY, F.W. Practical pig nutrition. 1. ed. Londres: Farming Press, 1976. 190p.

ZAVIEZO, D. Concepto de proteína ideal. Requerimentos de aminoácidos de pollos y gallinas. Avicultura Profesional, v18. n7, p. 18-22, 2000. 